\title{
Peritraumatic Distress: A Review and Synthesis of Fifteen Years of Research
}

Mary C. Vance, $\mathrm{MD}^{1}$; Benjamin Kovachy, BA ${ }^{3}$; Melissa Dong ${ }^{2,3}$; Eric Bui, MD, $\mathrm{PhD}^{2,3}$

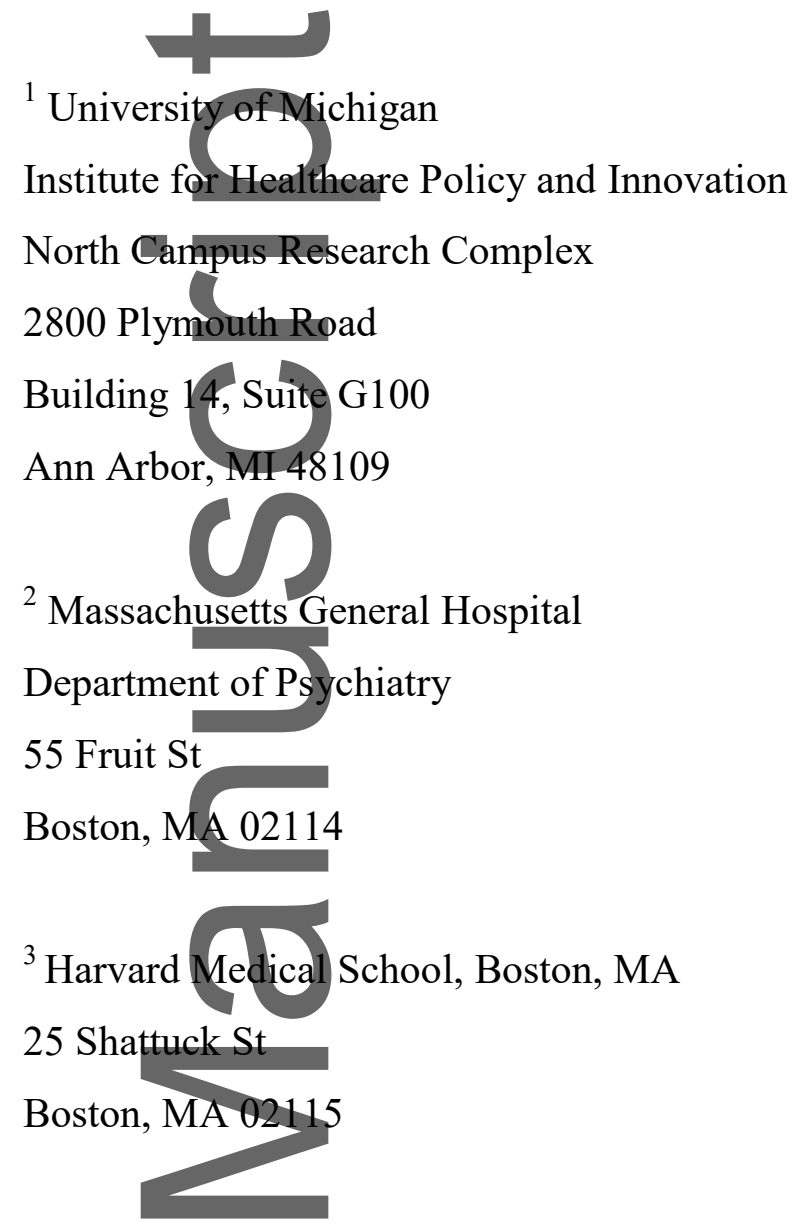

Short Title: Peritraumatic Distress: A Review and Synthesis

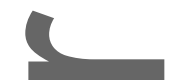

Keywords; peritraumatic distress; PTSD; trauma; review

Conflicts of Interest and Source of Funding: On behalf of all authors, the corresponding author declares that there are no conflicts of interest.

\section{Corresponding Author:}

Mary C. Vance, MD

Phone: (585) 766-2498

Email: marycv@med.umich.edu

This is the author manuscript accepted for publication and has undergone full peer review but has not been through the copyediting, typesetting, pagination and proofreading process, which may lead to differences between this version and the Version of Record. Please cite this article as doi: 10.1002/jclp.22612.

This article is protected by copyright. All rights reserved. 


\begin{abstract}
Context: While the subjective trauma exposure criterion was removed from the DSM-5 criteria set for posttraumatic stress disorder (PTSD), emerging literature suggests that peritraumatic distress may be useful in predicting outcomes after exposure to a stressful event.

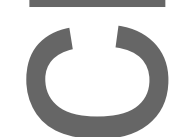

Method: We conducted a comprehensive review of the literature examining the association between peritraumatic distress and PTSD and other psychiatric outcomes. The 57 studies herein varied in both experimental design and target populations.

Results: Forty-eight studies found associations between peritraumatic distress and PTSD outcome measures, 23 found associations between peritraumatic distress and other psychiatric outcomes, and three found associations between peritraumatic distress and PTSDrelated symptoms or other psychiatric outcomes after non-Criterion-A stressful events by $D S M-5$ criteria.
\end{abstract}

Conclusion: Peritraumatic distress is associated with PTSD symptom severity, other psychiatric symptoms, and severity of PTSD-related symptoms after exposure to nonCriterion-A events, suggesting that peritraumatic distress is a risk factor for various psychiatric outcomes and furthering our understanding of the impact of subjective experience on trauma psychopathology.

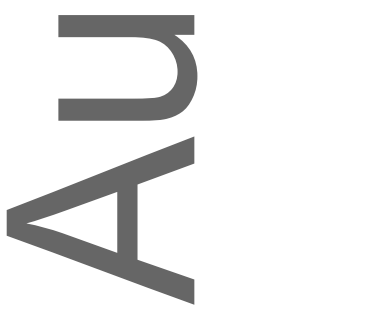




\section{INTRODUCTION}

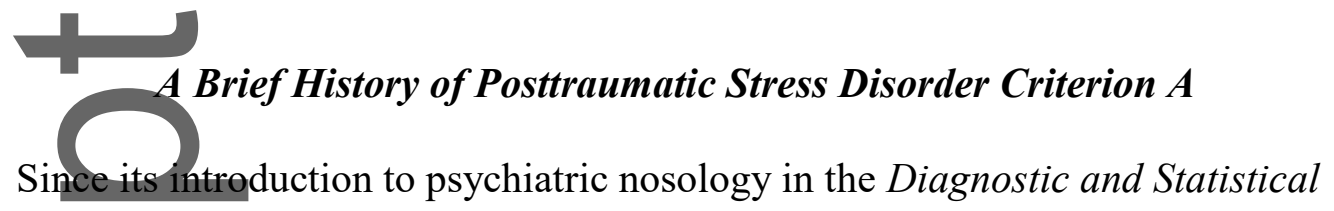

Manual, Third Edition (DSM-III), posttraumatic stress disorder (PTSD) has undergone several changes in its definition of Criterion A (the requirement for exposure to a traumatic event). These changes highlight the ongoing debate about whether trauma should be defined objectively, by event type; subjectively, by an individual's response to a potentially traumatic event; or both. A brief history of the evolution of PTSD Criterion A provides a revealing glimpse into these difficulties of defining traumatic stress.

Traumatic stress was first operationalized in the DSM-III's Criterion A as "a recognizable stressor that would evoke significant symptoms of distress of almost everyone" (American Psychiatric Association, 1980, p. 200). The accompanying text explained that events could qualify as traumatic if they were of a catastrophic nature and "generally outside the range of such common experiences as simple bereavement, chronic illness, business losses, or marital conflict." (American Psychiatric Association, 1980, p. 265) This definition of traumatic stress exposure thus emphasized its objective nature, and in neither the DSM-III diagnostic criteria nor its accompanying text was there mention of a subjective reaction to the trauma in the immediate vicinity of its occurrence. With the advent of the DSM-III-R, Criterion A formally defined a traumatic stressor as "an event that is outside the range of usual human experience" (American Psychiatric Association, 1987, p. 247). It also gave specific objective examples of qualifying stressors, and, for the first time, made reference in the accompanying text to a subjective peritraumatic stress reaction that is "usually experienced with intense fear, terror, and helplessness" (American Psychiatric Association, 1987, p. 247).

This article is protected by copyright. All rights reserved. 
The DSM-IV work group deliberated over whether Criterion A should continue to be objectively defined or whether explicit reference to the subjective peritraumatic response should be included (Davidson et al., 1996). A field trial examining the impact of alternative versions of Criterion A on the prevalence of the PTSD diagnosis found very little variation in prevalencerates whether or not a component of subjective peritraumatic reactions was added to an objective definition of trauma (Kilpatrick et al., 1998), suggesting that peritraumatic stress reactions have low positive predictive value (PPV) for PTSD. Despite this, the work group ultimately decided to split Criterion A into two parts, with Criterion A1 outlining an objective component ("the person experienced, witnessed, or was confronted with an event or events that involved actual or threatened death or serious injury, or a threat to the physical integrity of self or others") (American Psychiatric Association, 1994, p. 427) and Criterion A2 outlining a subjective component ('the person's response involved intense fear, helplessness, or horror") (American Psychiatric Association, 1994, p. 428).

In contrast, the DSM-5 work group reached a different consensus about the utility of a subjective trauma criterion: it decided to remove the subjective component of trauma from the PTSD diagnostic criteria. To support this decision, the work group cited evidence that Criterion A2 is poorly predictive of chronic PTSD, that peritraumatic reactions other than the explicitly listed "fear, helplessness, or horror" could also predict PTSD, and that a significant number of individuals may meet Criteria B-F after a Criterion A1 event without meeting Criterion A2 (Friedman, 2013; Friedman, Resick, Bryant, \& Brewin, 2011). At the same time, the objective Criterion A1 — now simply Criterion A-was expanded to include indirect work-related exposure to traumatic events (e.g., police officers reading details of child abuse, rescue workers handling human remains), and the definition of what constituted a qualifying indirect exposure was made more explicit (American Psychiatric Association, 2013). 
The winding course of development of the DSM's Criterion A for PTSD speaks to the ongoing debate about whether trauma should be defined objectively, subjectively, or both. The recent removal of Criterion A2 from the DSM-5 PTSD diagnostic criteria does not constitute a refutation of the subjective experience of trauma. On the contrary, this decision emphasizes its near-universality. Kilpatrick's field trial finding (Kilpatrick et al., 1998) that the prevalence of PTSD is not influenced by the presence of a peritraumatic stress criterion has been argued to suggest that peritraumatic stress reactions are so common that they are considered superfluous when used to diagnose PTSD in conjunction with objective criteria of traumatic stress. Since Kilpatrick's report, a number of other studies (Bedard-Gilligan \& Zoellner, 2008; Breslau \& Kessler, 2001; Schnurr, Spiro, Vielhauer, Findler, \& Hamblen, 2002) have emerged in support of the frequency with which Criterion A2 reactions occur in the context of trauma, which renders these reactions diagnostically redundant when used together with Criterion A1. Moreover, studies examining the independent utility of subjective peritraumatic reactions to predict PTSD have reported that individuals can meet DSM-IV Criteria B-F for PTSD without having experienced a Criterion A1 event (Bodkin, Pope, Detke, \& Hudson, 2007; Gold, Marx, Soler-Baillo, \& Sloan, 2005; Olde, van der Hart, Kleber, \& van Son, 2006) — although, of note, the idea that individuals can develop PTSD without a qualifying trauma is controversial (Pai, Suris, \& North, 2017), and it can be argued that the occurrence of psychiatric symptoms after a stressful but non-traumatic event is better diagnosed, as another psychiatric disorder (e.g., adjustment disorder). Finally, the subjective trauma criteria operationalized in Criterion A2 encompassed only the emotions of "fear, helplessness, and horror," which did not adequately capture the full range of peritraumatic emotional reactions that research has suggested to be predictive of PTSD (Brewin, Andrews, $\&$ Rose, 2000). For these reasons, it remains a priority to better understand the nature of subjective peritraumatic stress reactions. The rest of this review will focus on one construct, 
peritraumatic distress, that holds promise for elucidating these reactions, framed in the context of a reliable and validated instrument that originally spurred its development, the Peritraumatic Distress Inventory (PDI).

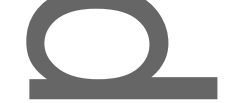

Peritraumatic Distress and the Peritraumatic Distress Inventory

Following the emergence of DSM-IV PTSD Criterion A2 describing the "fear, helplessness, or horror" thought to be inherent in a person's peritraumatic stress reactions, considerableresearch efforts were geared towards elucidating the association between subjective peritraumatic responses and PTSD symptomatology. Studies of peritraumatic responses have shown that a variety of physiological, emotional, and cognitive responses occur in the context of exposure to a trauma, above and beyond what was described in the $D S M-I V$ Criterion A2. These include heightened emotional and physiological arousal, such as a sense of personal life threat (March, 1993); fear; feelings of helplessness, horror, guilt, and anger (Bernat, Ronfeldt, Calhoun, \& Arias, 1998; Brewin et al., 2000; Ehlers, Mayou, \& Bryant, 1998; Roemer, Litz, Orsillo, Ehlich, \& Friedman, 1998); shame; loss of bowel and bladder control (Lehman, 1985; Solomon, Laor, \& McFarlane, 1996); and shaking, trembling, and increased heart rate (Bernat et al., 1998; Resnick, 1997; Shalev et al., 1998; Tucker, Dickson, Pfefferbaum, McDonald, \& Allen, 1997).

In the context of these findings, and with the stated goal of "creating an inventory of immediate responses to trauma" to aid in the understanding of how PTSD develops, Brunet and colleagues developed and validated the psychometric properties of the Peritraumatic Distress Inventory (PDI; Brunet et al., 2001, p. 1480). They described a 13-item self-rated questionnaire with instructions for the rater to report the extent to which each item was experienced "during and immediately after" a critical incident. Items were scored on a Likert scale from 0 (not true at all) to 4 (extremely true) and assessed responses ranging from 
emotional ("I felt helpless to do more," "I felt sadness and grief") to physiological ("I had difficulty controlling my bowel and bladder," "I had physical reactions like sweating, r shaking, and pounding heart") to cognitive ("I thought I might die"). In a cross-sectional sample of $n=702$ police officers and $n=301$ matched non-police controls, the PDI was found to be internally consistent, with good test-retest reliability and good convergent and divergent validity (Brunet et al., 2001).

Following this study, the PDI was increasingly utilized in research and clinical contexts. It was further validated for use in other languages, specifically French (Jehel, Brunet, Paterniti, \& Guelfi, 2005) and Japanese (Nishi et al., 2009) as well as in a specific population (i.e., children; (Bui et al., 2011). In addition, a Creole translation of the PDI was found to be internally consistent with a Cronbach's alpha of 0.82 (Derivois, Cénat, Joseph, Karray, \& Chahraoui, 2017). The term "peritraumatic distress"—-defined as a set of physiological, emotional, and cognitive responses that occur at and immediately after the time of a trauma- became common parlance for describing subjective peritraumatic reactions both meeting and exceeding Criterion A2. Although Brunet et al. (2001) originally pointed out the utility of the PDI as a measure of Criterion A2, the research literature already available at the time suggested that Criterion A2 actually encompassed only a small subset of possible peritraumatic stress reactions, and that the PDI assessed a broader range of such reactions, all of which fell under the umbrella of subjective immediate responses to trauma. The creation of this inventory, therefore, operationalized the construct of peritraumatic distress and made it possible to assess with a validated instrument a broader range of the subjective experience of trauma. This started the field on the path of clarifying how the subjective experience of trauma can contribute to the development of PTSD.

Moreover, the PDI enabled the systematic study of peritraumatic distress as a distinct phenomenon that, although originally constructed to aid in the diagnosis of PTSD, could be 
applied across diagnostic categories to characterize the role that subjective stress reactions play in the development of other disorders as well. In this way, peritraumatic distress could be conceptualized as a construct that comprehensively encapsulates an individual's subjective experience during and immediately after trauma and aids in the diagnosis of trauma-related sequelae including, but not limited to, PTSD.

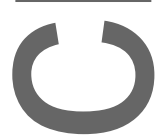

\section{The Current Study}

Since the introduction of the peritraumatic distress construct and the PDI in 2001, a number of studies have emerged examining the association between peritraumatic distress and psychopathology, including but not limited to PTSD. The only review on this topic published to date is a 2012 meta-analysis (Thomas, Saumier, \& Brunet, 2012) that assessed the correlation between peritraumatic distress as measured by the PDI and PTSD symptoms, after accounting for the time elapsed between the traumas and PDI and PTSD symptom assessments. This meta-analysis systemically reviewed the French- and English-language literature and included 22 studies after the application of inclusion and exclusion criteria. It found a correlation of $0.55(95 \% \mathrm{CI}=0.49$ to 0.61 , outcome of homogeneity analysis significant at Cochran' $Q=68.93, d f=19, p<0.001$ ) between PDI score and PTSD symptoms and demonstrated no significant effect of time elapsed between trauma and PTSD symptom assessment on the correlation between PDI and PTSD symptoms overall. However, meta-regression analyses conducted separately on studies with early (20-867 days) versus late (90-5987 days) PDI assessments showed that there was a time-dependent reduction in correlation between PDI and PTSD symptoms in the late PDI assessment group $(\beta=-0.59, p$ $<0.05)$. Although this study was comprehensive regarding its stated goals and yielded a high quality of evidence as a meta-analysis, it was limited in that it examined only adults (one 
study on children was excluded because the PDI had not been validated for children at that time) and examined PTSD, as defined by DSM-IV Criterion A1, as its only outcome.

The current study aims to comprehensively review and synthesize the past 15 years of research on peritraumatic distress conducted using the PDI as a measurement instrument, including all age groups and including outcomes other than PTSD. The literature on peritraumatic distress from the introduction of the PDI in 2001 through November 2017 is comprehensively reviewed herein, with a focus on the following three questions about peritraumatic distress as measured by the PDI: 1) is peritraumatic distress associated with PTSD symptoms?: 2) is peritraumatic distress associated with symptoms of psychiatric outcomes other than PTSD?; and 3) is peritraumatic distress associated with psychiatric outcomes even after non-Criterion-A events?

We will also discuss the potential implications of peritraumatic distress for future research, including within approaches, such as the Research Domain Criteria (RDoC), that conceptualize mental illness from a dimensional perspective. It is hoped that this review and synthesis will both summarize the research findings thus far and clarify the future research trajectory and potential clinical applications of the construct. Please note that the construct of peritraumatic dissociation, although related to peritraumatic distress, will not be specifically discussed as part of this review except to indicate when it has been controlled for in the studies we assessed.

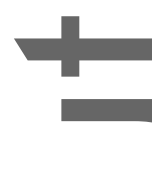

\section{METHODS}

We conducted a comprehensive search of the scientific literature using the PubMed, MEDLINE, and PILOTS databases for studies published in English and French from the introduction of the PDI in September 2001 through November 2017 using the keywords 
"peritraumatic distress," "peritraumatic stress," and "peritraumatic reaction." To complete the search, relevant articles were extracted from the references section of the manuscripts found r

in the initial literature search. We also extracted the following methodological features of each article: sample size and composition, study design, peritraumatic distress inventory used, psychological outcome assessed (PTSD, eating disorders, etc.), time at which symptoms were measured in relation to the traumatic event, and strength of the association between the distress reported and the outcome assessed.

We restricted inclusion to studies that met the following two criteria: a) use of the PDI, due to its reliability, validity, and high frequency of use in evaluating peritraumatic distress; and b) report of association between peritraumatic distress as measured by the PDI and psychiatric outcomes. Both studies that found an association between peritraumatic distress and psychiatric outcomes, and those that did not find an association, were included. We excluded reviews, case reports, and non-peer-reviewed research papers. Studies that only assessed for a relation between peritraumatic distress and non-psychiatric outcomes (e.g., musculoskeletal pain) were also excluded.

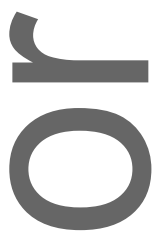

\section{RESULTS}

The initial literature search yielded 394 results, of which 29 were reviews and the rest either did not utilize the PDI or did not report an association between PDI and psychiatric outcomes. Additionally, two potentially relevant articles were not accessible to the authors. This resulted in a total of 57 articles that are included in the present review. 


\section{Study Characteristics}

Characteristics of each study, including author, year, sample population, trauma type, time elapsed between traumatic events and their assessments, outcomes measured, inventories used, and statistical values of significance are reported in Table 1. Assessments spanned multiple iterations of the DSM (i.e., both the DSM-IV and the DSM-5). Sample sizes in the studies ranged from $N=21$ to $N=1355$. The age ranges of participants included adults, children less than 18 years old, and elders aged 65 and up. Multiple specific populations were studied, including police officers, nurses, 911 telecommunicators, parents, pregnant women, rescue workers, and university students. Although population categories could overlap (e.g., 911 telecommunicators could also be parents), the studies specified the types of traumas they were assessing based on these categories (e.g., Pierce and Lilly (2012) only assessed "dutyrelated exposure to potentially traumatic calls"). Studies were also conducted across several countries, both in the developed world (e.g., US, France, Canada, New Zealand, Australia, the Netherlands, Japan) and in the developing world (e.g., Haiti, Brazil, Sri Lanka, Rwanda). Index traumas included natural or human-caused disasters (e.g., World Trade Center attack, earthquakes, floods, factory accidents), interpersonal traumas (e.g., assault, burglary), noninterpersonal traumas (e.g., medical illness, motor vehicle collision), and loss (i.e., sudden death of a loved one). In some studies, participants directly experienced trauma; in others, participants witnessed it as it was happening to others, were exposed to it indirectly through first responder work, or learned that it happened to a loved one. Some studies assessed the relation between peritraumatic distress and psychiatric outcomes after potentially stressful events that do not qualify as Criterion A traumas (i.e., non-worked-related media exposure to a disaster, childbirth). The time elapsed between the traumatic events and their assessments using the PDI ranged from less than 48 hours to greater than 12 years: i.e., in some studies, the PDI was used as a retrospective measure with considerable temporal distance from the 
time of the trauma. The time elapsed between the traumatic events and the assessed outcome measures ranged from less than one week (only in assessments for non-PTSD psychiatric outcomes) to greater than 12 years - although, of note, not all studies reported a precise follow-up time frame, and PTSD can only be diagnosed at least one month after an index event. The primary outcome assessed by the majority of studies was PTSD, but other outcomes were assessed as well, including depression, dissociation, posttraumatic growth, the effects of medieations (propranolol), biological measures (basal cortisol levels upon awakening, memory performance, traumatic grief, disordered eating, sleep disturbances, pain catastrophizing, and child behavior. As per our inclusion criteria, all peritraumatic distress assessments were performed using the original PDI or another variant (e.g., Japanese version, Creole version, French version, child version). Forty-seven of the 57 studies found a significant association between peritraumatic distress and psychiatric outcomes, while the remaining ten studies either did not find any association or did not find an association within a particular anatysis.
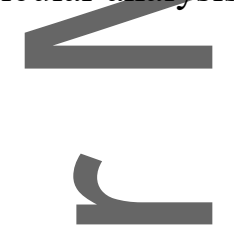

\section{Peritraumatic Distress and PTSD}

Fifty out of 57 studies examined the association between peritraumatic distress and PTSD symptoms, making PTSD by far the most common outcome measured in the studies reviewed. Both clinician-assessed and self-report measures of posttraumatic stress were utilized. The most common PTSD inventories used were the Impact of Event Scale Revised (IES-R), the Clinician-Administered PTSD Scale (CAPS), and the PTSD Checklist (PCL). Studies varied in design and included both cross-sectional studies and longitudinal studies. Some studies controlled for other variables, such as age, gender, witness status, and history of psychiatric illness. Some studies also examined associations between peritraumatic distress and specific PTSD criteria, including re-experiencing, intrusions, avoidance, and 
hyperarousal. In 48 of the 50 studies that examined the relation between the PDI and PTSD symptoms, a significant association between peritraumatic distress and at least one of the PTSD outcome-measures was reported.

However, seven studies either did not find an association overall (2/50 studies) or did not find an association within a particular analysis (5/50 studies). Kuhn et al. (2006) showed that the PDIwas associated with CAPS scores at one month, but not at three months or six months; and that the PDI was associated with PCL scores at one month and three months, but not at six months. Dickie et al.'s study (2008), which did not directly examine the association between peritraumatic distress and PTSD, found that the PDI did not mediate the relationship between memory performance and CAPS scores. Allenou et al.'s study (2010) of mothers and fathers after their children experienced a motor vehicle collision found that the PDI was associated with PCL scores in mothers but not in fathers. Maia et al. (2011) found no association between peritraumatic distress and PTSD Checklist Civilian (PCL-C) scores in active duty police officers. Letamendia et al. (2012) found that the PDI was associated with PCL scores at five weeks but not at three months. Hiar et al. (2016) found the PDI to be correlated with PCL scores at 12 months in a Pearson's correlation but not in multiple regressionanatysis. Finally, Tanisho et al. (2016) found the PDI to be associated with IES-R at baseline (2-3 months post-event) but not at follow-up (14-15 months post-event).

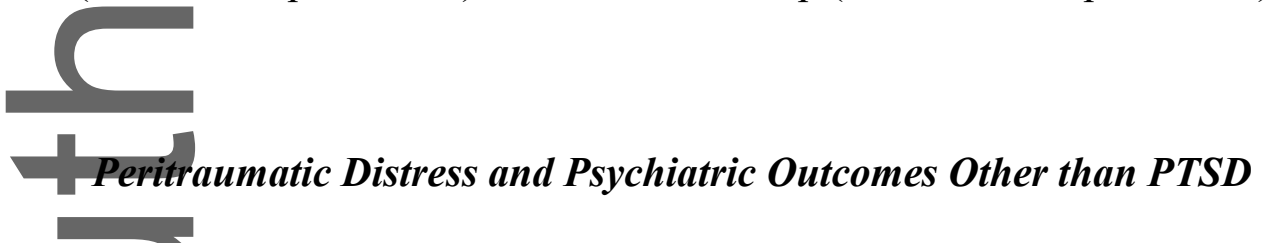

Twenty-four studies examined the association between peritraumatic distress and psychiatric outcomes other than PTSD, including acute stress disorder (ASD), anxiety, depression, sleep disturbances, complicated or traumatic grief, disordered eating, pain catastrophizing, and psychological distress. The vast majority $(23 / 24)$ of the studies showed 
positive correlations between peritraumatic distress and at least one of the outcomes measured.

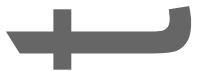

In a sample of fifty individuals after a motor vehicle collision, Kuhn et al. (2006) found that peritraumatic distress was associated with ASD symptoms two weeks after the collision. One validation study of the Japanese version of the PDI (Nishi et al., 2009) in $N=135$ individuals after a motor vehicle collision found that, in addition to being significantly associated with PTSD as assessed by the IES-R, peritraumatic distress was also significantly associated with the Hospital Anxiety and Depression Scale (HADS) total score and anxiety and depression subscores. Three other studies, one of $N=1355$ adults, one of $N=872$ children, and one of $N=128$ street children after an earthquake (Cénat \& Derivois, 2014, 2015; Derivois et al., 2017), found peritraumatic distress to be associated with depression symptoms as well as PTSD. One prospective study (Kunst, 2010) examining posttraumatic growth in $N=678$ ( $n=205$ at follow-up) survivors of violence found a significant linear relationship between peritraumatic distress and posttraumatic growth at baseline and six months. Another study (Kunst, 2012) examined the same population crosssectionally and found that peritraumatic distress was associated with posttraumatic growth. One prospective study (Bui et al., 2012) of $N=698$ ( $n=109$ at follow-up) individuals after watching media coverage of a recent earthquake in Japan found that, in addition to being associated with PTSD symptoms at two months, peritraumatic distress assessed less than one month after the event was associated with disruptive nocturnal sleep in the ten days after the event. In a study of $N=125$ adults after a loved one's sudden death, Hargrave et al. (2012) found that peritraumatic distress was associated with both PTSD and complicated grief symptoms. Similarly, a study of $N=102$ individuals after the death of a family member in the Rwandan genocide found peritraumatic distress to be a mediator of traumatic grief symptoms 
(Mutabaruka, Séjourné, Bui, Birmes, \& Chabrol, 2012). One prospective study (Rodgers, Franko, Brunet, Herbert, \& Bui, 2012) assessed disordered eating symptoms in $N=698$ ( $n=113$ at follow-up) individuals after exposure to media coverage of an earthquake and found that peritratmatic distress was associated with bulimia in hierarchical regression analysis. In a sample of $N=1039$ adults after a motor vehicle collision, Pereira et al. (2014) found an association between peritraumatic distress and pain catastrophizing as measured by the 13-item Pain Catastrophizing Scale.

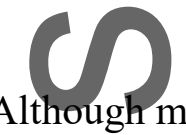

Although most studies found an association between peritraumatic distress and psychiatric outcomes other than PTSD, five studies did not show an association between the two either overall or within a particular analysis. Simeon et al. (2008) examined 21 individuals highly exposed to the 9/11 World Trade Center attacks and found that the PDI was significantly associated with CAPS scores but not dissociation as measured by the Dissociative Experiences Scale (DES). McCaslin et al.'s assessment (2009) of Sri Lankan university students found that the PDI was significantly associated with PTSD Checklist Specific (PCL-S) scores but not with posttraumatic growth as assessed by the Posttraumatic Growth Inventory (PTGI). Rodgers et al. (2012) found that the PDI predicted bulimia but not oral control, dieting, or composite disordered eating symptoms as assessed by the 26-Item Eating Attitudes Test (EAT-26) after media exposure to the March 2011 Japan earthquake. Hiar et al.'s study (2016) of individuals after the Arab Spring riots in Tunisia found that the PDI was not independently associated with somatic symptoms as assessed by the Patient Health Questionnaire (PHQ) at 12 months in multiple regression analysis. Finally, Tanisho et al.'s study (2016) of survivors of two nuclear power plant accidents found that the PDI predicted psychological distress as assessed by the Kessler Psychological Distress Scale (K6) at baseline but not at a follow-up interval of 14-15 months. 


\section{Peritraumatic Distress and Psychiatric Outcomes after Non-Criterion-A Events}

Three of the studies reviewed herein assessed the association between peritraumatic distress and psychiatric outcomes after events that do not meet the PTSD DSM-5 Criterion A. Similar to studies in populations experiencing a Criterion A trauma, all of these studies found that the degree of peritraumatic distress experienced was associated with the development of psychiatric sequelae, including PTSD-related symptoms (symptoms qualifying for PTSD Criteria $\mathrm{B}+\mathrm{H}$ but not for Criterion $\mathrm{A})$.

In two studies (Bui et al., 2012; Rodgers et al., 2012), peritraumatic distress and its relation to psychiatric disorders was assessed after media exposure to a traumatic event. As described above, one study (Bui et al., 2012) of $N=698$ ( $n=109$ at follow-up) individuals who watched media coverage of a recent Japanese earthquake found that peritraumatic distress was associated with both PTSD-related symptoms and disruptive nocturnal sleep. Another prospective study (Rodgers et al., 2012) found that, in $N=698$ ( $n=113$ at follow-up) individuals who were exposed to media coverage of an earthquake, peritraumatic distress was associated with bulimia symptoms. Finally, one study (Boudou, Séjourné, \& Chabrol, 2007) found that peritraumatic distress was associated with PTSD-related symptoms in a sample of $N=117$ women assessed six weeks after childbirth (which does not classically qualify as a Criterion A trauma in the DSM-5, although the authors argue that the experience of childbirth can be traumatic)

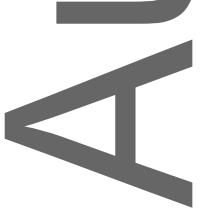




\section{DISCUSSION}

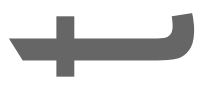

In this comprehensive review and synthesis of 15 years of research into the

peritraumatic distress construct, we first placed peritraumatic distress in its historical context by providing background information on the evolving conceptualization of trauma. We provided an overyiew of the changing definition of Criterion A for PTSD in the DSM, which encapsulates the tension in the modern understanding of traumatic stress between objective and subjective definitions of trauma. We then described the efforts made over the past several decades to better understand the subjective experience of distress during and immediately after exposure to a traumatic event, and the way in which consolidating these distressing experiences into the single construct of peritraumatic distress resulted in the formation of Brunet and colleagues' Peritraumatic Distress Inventory (PDI).

Following this introduction, we comprehensively reviewed the literature on peritraumatic distress for published articles that used the PDI to assess for the association between peritraumatic distress and psychiatric outcomes, including but not limited to PTSD. Our review supports an association between peritraumatic distress and PTSD symptom severity, in both cross-sectional and prospective observational studies, across multiple age groups, in a variety of cultural contexts, after multiple types of trauma, and after varying degrees of proximity to the trauma. We also found an association between peritraumatic distress and psychiatric sequelae other than PTSD, including complicated/traumatic grief, sleep problems, and disordered eating. Our review also suggests that peritraumatic distress experienced after stressful events that do not meet DSM-5 Criterion A for PTSD can nevertheless result in PTSD-related symptoms as well as other negative psychiatric outcomes in individuals exposed to them. 
Although the majority (47/57) of the studies we included in this review found an association between peritraumatic distress and the measured psychiatric outcomes, the remaining ten studies either did not find an association overall $(2 / 10)$ or did not find an association within at least one particular analysis $(8 / 10)$. While the weight of the evidence does suggest peritraumatic distress as a risk factor for psychiatric outcomes including but not limited to PTSD, some reasons for why these ten studies did not find an association can be posited. For example, three of the ten studies (Kuhn et al., 2006; Letamendia et al., 2012; Tanisho et al., 2016) found an association between peritraumatic distress and PTSD at shorter-term but not at longer-term follow-up, which suggests that the association between the PDI and PTSD symptoms may decrease over time. On the other hand, these studies' findings stand in eontrast to those of multiple other studies in our review showing an association between peritraumatic distress and PTSD up to several years after the traumatic event occurred. Additionally, five of the ten studies demonstrated no association between peritraumatic distress and a psychiatric outcome other than PTSD—namely, posttraumatic growth (McCaslin et al., 2009); oral control, dieting, and composite disordered eating symptoms(Rodgers et al., 2012); somatic symptoms (Hiar et al., 2016); and psychological distress (Tanisho et al., 2016). This raises the question of whether peritraumatic distress is as robust of a risk factor for the development of psychiatric sequelae other than PTSD, although of note two other studies (Kunst, 2012; Nishi et al., 2016) did find an association between peritraumatic distress and posttraumatic growth.

From the clinical perspective, assessing peritraumatic distress as a potential risk factor in the development of adverse psychiatric outcomes might be useful in triaging patients into lower-risk and higher-risk groups after experiencing a traumatic event, in order to institute preventative and early treatment measures in case psychiatric sequelae do develop. When 
used as screening tools, instruments with high sensitivity and a high negative predictive value are desired. In one study (Nishi et al., 2010) of $N=79$ individuals admitted to an intensive care unit after a motor vehicle collision, PDI scores were found to be predictive of PTSD, and a cutoff score of 23 achieved maximal sensitivity (77\%) and specificity (82\%), with a negative predictive value of $93 \%$ and a positive predictive value of $53 \%$. Further validation studies of the PDI to find a cutoff score that maximizes its sensitivity and negative predictive value would improve the utility of this instrument as a screening tool.

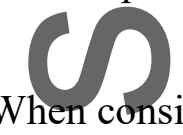

in mind that, while our review provides evidence for an association between peritraumatic distress and psychopathology, it cannot posit a causal link between the two (i.e., it cannot show that peritraumatic distress causes psychopathology). Therefore, based on the current evidence, peritraumatic distress can at best be considered a risk factor for developing psychiatric sequelae after experiencing trauma. In addition, other literature has demonstrated that most individuals exposed to potentially traumatic events do not go on to develop PTSD (Cahill \& Pontoski, 2005) and that certain early interventions, such as psychological debriefing, have not been shown to be useful for preventing PTSD after traumatic incidents (Rose, Bisson, Churchill, \& Wessely, 2002). These findings should be considered if designing early interventions aimed at reducing the risk of PTSD, in order to avoid overtreatment and potential harm in the peritraumatic and short-term posttraumatic setting. r

From the research perspective, the study of peritraumatic distress can be seen as a dimensional, rather than categorical, approach to the etiology and mechanisms of psychopathology. Evidence suggests that peritraumatic distress may be a transdiagnostic variable, and thereby useful in furthering our understanding of the underpinnings of multiple syndromic processes that share a common root. As such, the potential applications of the 
peritraumatic distress construct accord well with the NIMH's Research Domain Criteria (RDoC) initiative to integrate multiple levels of research findings to better understand the full dimensional range of human behaviors, from normal to pathological.

Some background on the $\mathrm{RDoC}$ is given here for context. In recent years, as part of an NIMH initiative to incorporate the past several decades of research in genetics, neuroscience, and behavioral science into the research framework upon which investigations are funded and further theoretical developments are based, a non-categorical, dimensional approach to the classification of mental illnesses known as the RDoC was proposed. The RDoC taxonomic system is designed to facilitate psychiatric research in a way that takes into account the rapidly accumulating body of evidence on the neurobiological correlates of mental illness and does not constrain future research efforts into categorical, syndromic diagnoses that may not reflect the true underpinnings of the phenomena being described. The five dimensional constructs thus far proposed in the RDoC are Negative Valence Systems, Positive Valence Systems, Cognitive Systems, Social Processes, and Arousal and Regulatory Systems. Beneath the overarching rubric of each construct fall several subconstructs (e.g., for the construct of Negative Valence-Systems, there is the subconstruct of acute threat/“fear"), and each of these subconstructs can be further broken down into units of analysis: i.e., genes, molecules, cells, circuits, physiology, behavior, self-reports, and paradigms ("RDoC Matrix").

Based on the evidence that peritraumatic distress is associated with PTSD as well as other psychiatrie sequelae in a variety of populations after multiple types of traumatic events, it appears to be a phenomenon that cuts across current DSM diagnoses and is applicable to varying populations and psychopathologies. Therefore, peritraumatic distress may be a promising lead for further study within the "self-report" unit of analysis under the Negative Valence Systems construct and the acute threat/“fear" subconstruct, using the PDI as its 
validated self-report measure. Additionally, further research into the biological factors that play into the peritraumatic distress response, including its genetic underpinnings and neurocircuitry as well as its physiologic correlates (some of which, like urinary or fecal incontinence or autonomic responses such as palpitations and diaphoresis, are assessed in the PDI), may also further our understanding of the "genes," "circuits," and "physiology" units of analysis.

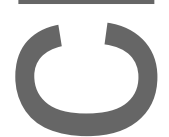

Seyeral timitations should be considered when interpreting the results of this review. Firstly, the review only assessed studies that utilized the PDI as their measure of peritraumatic distress, and this raises the question of whether the review is a true construct evaluation or the evaluation of a specific instrument. Other measures of peritraumatic distress are utilized in the literature. For example, the military-specific Peritraumatic Behavior Questionnaire (PBQ) assesses combat-related peritraumatic distress and dissociation and has shown good internal consistency and validity as both a self-rated measure and an observerrated measure (Agorastos et al., 2013, 2016). Other studies have used the Detailed Assessment of Posttraumatic Stress, a 105-item self-report inventory that contains a peritraumatic distress subscale (Briere et al., 2017; Briere, Scott, \& Weathers, 2005). Still others have utilized the $D S M-I V$ Criterion A2 by using three questions to assess peritraumatic fear, helplessness, and horror (Blix, Hansen, Birkeland, Nissen, \& Heir, 2013; Boelen, 2015). In the myoeardial infarction literature, multiple studies have assessed peritraumatic reactions using three questions about fear of dying, helplessness, and pain (Meister et al., 2016; von Känel, Hari, Sehmid, Saner, \& Begré, 2011; Wiedemar et al., 2008). However, we found the PDI to surpass other measures in terms of reliability and validity across populations and languages and in terms of frequency of use (the PDI was used in the majority of studies on peritraumatic distress in our literature search). Therefore, we believe that our review offers an 
understanding of the peritraumatic distress construct that, although incomplete, is couched within a reliable and validated instrument that is also the most commonly used.

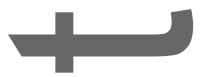

Secondly, the PDI was originally validated and intended for use in survivors of Criterion A traumas (Brunet et al., 2001). Although it has since been further validated for use in anotherpopulation (Bui et al., 2011) and in other languages (Jehel et al., 2005; Nishi et al., 2009), there have been to our knowledge no validation studies in individuals who did not experience Criterion A traumas. This should be taken into account when interpreting the results of studies assessing the relation between peritraumatic distress and the development of psychiatric outcomes after non-Criterion-A traumas. Thirdly, the studies varied in the timeframe within which they administered the PDI and assessed PTSD symptoms after the index event, and recall accuracy is likely to decrease as more time elapses (Lacy \& Stark, 2013). Fourthly, as with any study that relies on participant self-report, using retrospective assessments of peritraumatic distress in the form of subjective questionnaires introduces the risk of recall bias. For example, the presence of a PTSD diagnosis has been suggested to impact the reporting of peritraumatic distress: in one study that examined participants' retrospective PDI scores for a traumatic event, those with persistent PTSD displayed a lower test-retest correlation in their PDI scores compared to those who did not develop PTSD or had remitting PTSD (David, Akerib, Gaston, \& Brunet, 2010). This calls into question the stability of retrospective PDI scores, particularly in individuals with persistent PTSD. Fifthly, PTSD symptoms were assessed using different inventories in the studies, including both selfrated and elinician-rated scales. This raises the question of reliability in the diagnosis of PTSD between studies. And lastly, only one or a few outcomes (e.g., PTSD, complicated grief, etc.) were examined in each study, which could have led to other mental health outcomes being missed. 
There are multiple questions that remain unanswered in the study of peritraumatic distress and its predictive value for psychopathology. Further research is needed to better characterize the psychological, physiological, and cognitive phenomena within the peritraumatic distress construct and the range of psychiatric outcomes with which it is associated. Specifically, more longitudinal and prospective studies of peritraumatic distress and its effects in different populations, including children and the elderly, and in nonWesternized cuttures, are needed. Early assessment (within hours) of peritraumatic distress after the index event would be useful in accurately screening for peritraumatic distress and mitigating recall bias. The use of interviewer-rated questionnaires for psychiatric outcomes, in addition to the self-rated questionnaires found in many of the studies so far, would add a layer of validity. Additionally, studies on the neurocognitive and genetic correlates of peritraumatic distress would be useful in teasing out the biological underpinnings of this phenomenon, including biomarker, neuroimaging, and genomic studies.
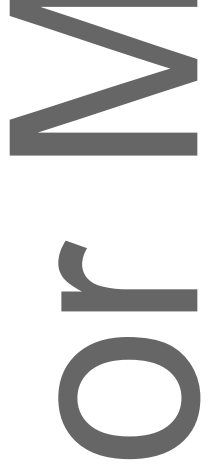
CONCLUSIONS

In this comprehensive review and synthesis of the last 15 years of research on peritraumatic distress using the PDI, we found that peritraumatic distress as assessed by the may be use PDI may be useful in predicting PTSD symptom severity, other psychiatric symptoms, and severity of PTSD-related symptoms after exposure to non-Criterion-A events in a variety of experimental designs and target populations. These findings suggest that peritraumatic distress may be arisk factor in the development of psychopathology, including but not limited to PTSD, and that the PDI may have utility as a validated self-report measure of 
peritraumatic distress. In light of the evolving definition of trauma over the past several decades, and the recent changes in DSM diagnostic criteria for PTSD, peritraumatic distress holds promise as a construct that can be used to improve our knowledge of subjective peritraumatic responses. Further research into peritraumatic distress, using the RDoC framework to study this construct in a way that cuts across DSM diagnoses, could prove useful in furthering our understanding of the development of trauma-related disorders from a dimensional perspective.

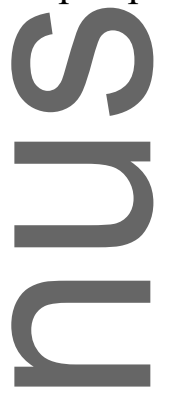

\section{REFERENCES}

Agorastos, A., Angkaw, A. C., Johnson, H. E., Hansen, C. J., Cook, C. V., \& Baker, D. G. (2016). Peritraumatic Behavior Questionnaire - Observer Rated: Validation of the objective version of a measure for combat-related peritraumatic stress. World Journal of Psychiatry, 6(2), 226-232. https://doi.org/10.5498/wjp.v6.i2.226

Agorastos-A., Nash, W. P., Nunnink, S., Yurgil, K. A., Goldsmith, A., Litz, B. T., ... Baker,

D. G. (2013). The Peritraumatic Behavior Questionnaire: Development and initial validation of a new measure for combat-related peritraumatic reactions. $B M C$

Psychiatry, 13, 9. https://doi.org/10.1186/1471-244X-13-9

Allenou, C., Olliac, B., Bourdet-Loubère, S., Brunet, A., David, A.-C., Claudet, I., ... Birmes, P. (2010). Symptoms of traumatic stress in mothers of children victims of a motor vehicle accident. Depression and Anxiety, 27(7), 652-657.

https://doi.org/10.1002/da.20650 
American Psychiatric Association. (1980). Diagnostic and Statistical Manual of Mental Disorders (3rd ed.). Washington, DC: Author.

American Psychiatric Association. (1987). Diagnostic and Statistical Manual of Mental Disorders (3rd ed., text rev.). Washington, DC: Author.

American Psychiatric Association. (1994). Diagnostic and Statistical Manual of Mental Disorders (4th ed.). Washington, DC: Author.

American Psychiatric Association. (2013). Diagnostic and Statistical Manual of Mental Disorders (5th ed.). Washington, DC: Author.

Apfel, B. A., Otte, C., Inslicht, S. S., McCaslin, S. E., Henn-Haase, C., Metzler, T. J., ... Marmar, C. R. (2011). Pretraumatic prolonged elevation of salivary MHPG predicts peritraumatic distress and symptoms of post-traumatic stress disorder. Journal of Psychiatric Research, 45(6), 735-741.

https://doi.org/10.1016/j.jpsychires.2010.11.016

Bedard-Gilligan, M., \& Zoellner, L. A. (2008). The utility of the A1 and A2 criteria in the diagnosis of PTSD. Behaviour Research and Therapy, 46(9), 1062-9.

https://doi.org/10.1016/j.brat.2008.06.009

Berna, G., Vaiva, G., Ducrocq, F., Duhem, S., \& Nandrino, J. L. (2012). Categorical and dimensional study of the predictive factors of the development of a psychotrauma in victims of car accidents. Journal of Anxiety Disorders, 26(1), 239-245.

https://doi.org/10.1016/j.janxdis.2011.11.011

Bernat, J. A., Ronfeldt, H. M., Calhoun, K. S., \& Arias, I. (1998). Prevalence of traumatic events and peritraumatic predictors of posttraumatic stress symptoms in a nonclinical sample of college students. Journal of Traumatic Stress, 11(4), 645-664.

https://doi.org/10.1023/A:1024485130934 
Birmes, P. J., Brunet, A., Coppin-Calmes, D., Arbus, C., Coppin, D., Charlet, J.-P., ...

Schmitt, L. (2005). Symptoms of peritraumatic and acute traumatic stress among

victims of an industrial disaster. Psychiatric Services (Washington, D.C.), 56(1), 93-

95-https./doi.org/10.1176/appi.ps.56.1.93

Blanc, J., Bui, E., Mouchenik, Y., Derivois, D., \& Birmes, P. (2015). Prevalence of posttraumatic stress disorder and depression in two groups of children one year after the January 2010 earthquake in Haiti. Journal of Affective Disorders, 172, 121-126.

https://doi,org/10.1016/j.jad.2014.09.055

Blanc, J., Rahill, G. J., Laconi, S., \& Mouchenik, Y. (2016). Religious beliefs, PTSD, depression and resilience in survivors of the 2010 Haiti earthquake. Journal of Affective Disorders, 190, 697-703. https://doi.org/10.1016/j.jad.2015.10.046

Blix, I., Hansen, M. B., Birkeland, M. S., Nissen, A., \& Heir, T. (2013). Posttraumatic growth, posttraumatic stress and psychological adjustment in the aftermath of the 2011 Osto-bombing attack. Health and Quality of Life Outcomes, 11, 160. https://doi.org/10.1186/1477-7525-11-160

Bodkin, J.A., Pope, H. G., Detke, M. J., \& Hudson, J. I. (2007). Is PTSD caused by traumatic stress? Journal of Anxiety Disorders, 21(2), 176-82.

https://doi.org/10.1016/j.janxdis.2006.09.004

Boelen, P.A. (2015). Peritraumatic distress and dissociation in prolonged grief and posttraumatic stress following violent and unexpected deaths. Journal of Trauma \& Dissociation: The Official Journal of the International Society for the Study of Dissociation (ISSD), 16(5), 541-550.

https://doi.org/10.1080/15299732.2015.1027841

Boudou, M., Séjourné, N., \& Chabrol, H. (2007). Childbirth pain, perinatal dissociation and perinatal distress as predictors of posttraumatic stress symptoms. Gynecologie, 
Obstetrique \& Fertilite, 35(11), 1136-1142.

https://doi.org/10.1016/j.gyobfe.2007.09.014

Breslau, N., \& Kessler, R. C. (2001). The stressor criterion in DSM-IV posttraumatic stress disorder: An empirical investigation. Biological Psychiatry, 50(9), 699-704.

Brewin, C.R., Andrews, B., \& Rose, S. (2000). Fear, helplessness, and horror in posttraumatic stress disorder: Investigating DSM-IV criterion A2 in victims of violent crime. Journal of Traumatic Stress, 13(3), 499-509.

https://doi.org/10.1023/A:1007741526169

Briere, J., Dias, C P., Semple, R. J., Scott, C., Bigras, N., \& Godbout, N. (2017). Acute stress symptoms in seriously injured patients: Precipitating versus cumulative trauma and the contribution of peritraumatic distress. Journal of Traumatic Stress, 30(4), 381388. https.//doi.org/10.1002/jts.22200

Briere, J., Scott, C., \& Weathers, F. (2005). Peritraumatic and persistent dissociation in the presumed etiology of PTSD. The American Journal of Psychiatry, 162(12), 22952301. https://doi.org/10.1176/appi.ajp.162.12.2295

Brock, R. L., O’Hara, M. W., Hart, K. J., McCabe-Beane, J. E., Williamson, J. A., Brunet, A. . King, S. (2015). Peritraumatic Distress Mediates the Effect of Severity of Disaster Exposure on Perinatal Depression: The Iowa Flood Study. Journal of Traumatic Stress, 28(6), 515-522. https://doi.org/10.1002/jts.22056

Brunet, $\mathrm{A}_{1}$, Sanche, S., Manetti, A., Aouizerate, B., Ribéreau-Gayon, R., Charpentier, S., ... Arbus, C. (2013). Peritraumatic distress but not dissociation predicts posttraumatic stress disorder in the elderly. International Psychogeriatrics, 25(6), 1007-1012. https://doi.org/10.1017/S1041610213000069

Brunet, A., Weiss, D. S., Metzler, T. J., Best, S. R., Neylan, T. C., Rogers, C., ... Marmar, C. R. (2001). The Peritraumatic Distress Inventory: A proposed measure of PTSD 
criterion A2. American Journal of Psychiatry, 158(9), 1480-5.

https://doi.org/10.1176/appi.ajp.158.9.1480

Bui, E., Brunet, A., Allenou, C., Camassel, C., Raynaud, J.-P., Claudet, I., ... Birmes, P. (2010). Peritraumatic reactions and posttraumatic stress symptoms in school-aged children victims of road traffic accident. General Hospital Psychiatry, 32(3), 330-

333.https://doi.org/10.1016/j.genhosppsych.2010.01.014

Bui, E., Brunet, A., Olliac, B., Very, E., Allenou, C., Raynaud, J.-P., ... Birmes, P. (2011).

Validation of the Peritraumatic Dissociative Experiences Questionnaire and

Peritraumatic Distress Inventory in school-aged victims of road traffic accidents.

European Psychiatry: The Journal of the Association of European Psychiatrists,

26(2), 108-111. https://doi.org/10.1016/j.eurpsy.2010.09.007

Bui, E., Joubert, S., Manetti, A., Camassel, C., Charpentier, S., Ribereau-Gayon, R., ... Arbus, C. (2010). Peritraumatic distress predicts posttraumatic stress symptoms in older people. International Journal of Geriatric Psychiatry, 25(12), 1306-1307. https://do1.org/10.1002/gps.2445

Bui, E., Rodgers, R. F., Herbert, C., Franko, D. L., Simon, N. M., Birmes, P., \& Brunet, A. (2012). The impact of internet coverage of the March 2011 Japan earthquake on sleep and posttraumatic stress symptoms: An international perspective. American Journal of Psychiatry, 169(2), 221-2. https://doi.org/10.1176/appi.ajp.2011.11081281

Bui, E., Tremblay, L., Brunet, A., Rodgers, R., Jehel, L., Véry, E., .. Birmes, P. (2010). Course of posttraumatic stress symptoms over the 5 years following an industrial disaster: A structural equation modeling study. Journal of Traumatic Stress, 23(6), 759-766. https://doi.org/10.1002/jts. 20592

Cahill, S. P., \& Pontoski, K. (2005). Post-Traumatic Stress Disorder and Acute Stress Disorder I. Psychiatry (Edgmont), 2(4), 14-25. 
Cénat, J. M., \& Derivois, D. (2014). Assessment of prevalence and determinants of posttraumatic stress disorder and depression symptoms in adults survivors of earthquake in Haiti after 30 months. Journal of Affective Disorders, 159, 111-7. https://doi.org/10.1016/j.jad.2014.02.025

Cénat, J. M., \& Derivois, D. (2015). Long-term outcomes among child and adolescent survivors of the 2010 Haitian earthquake. Depression and Anxiety, 32(1), 57-63. https://doi.org/10.1002/da.22275

David, A.CC, Akerib, V., Gaston, L., \& Brunet, A. (2010). Consistency of retrospective reports of peritraumatic responses and their relation to PTSD diagnostic status. Journal of Traumatic Stress, 23(5), 599-605. https://doi.org/10.1002/jts.20566

Davidson, J. R. T., Foa, E. B., Blank, A. S., Brett, E. A., Fairbank, J., Green, B. L., \& Rothbaum, B. O. (1996). Posttraumatic stress disorder (Vol. 2). Washington, DC: American Psychiatric Association.

Derivois, D., Cenat, J. M., Joseph, N. E., Karray, A., \& Chahraoui, K. (2017). Prevalence and determinants of post-traumatic stress disorder, anxiety and depression symptoms in street children survivors of the 2010 earthquake in Haiti, four years after. Child Abuse \& Neglect, 67, 174-181. https://doi.org/10.1016/j.chiabu.2017.02.034

Dickie, E. W., Brunet, A., Akerib, V., \& Armony, J. L. (2008). An fMRI investigation of memory encoding in PTSD: Influence of symptom severity. Neuropsychologia, 46(5), 1522-1531. https://doi.org/10.1016/j.neuropsychologia.2008.01.007

Ehlers, A., Mayou, R. A., \& Bryant, B. (1998). Psychological predictors of chronic posttraumatic stress disorder after motor vehicle accidents. Journal of Abnormal Psychology, 107(3), 508-519. https://doi.org/10.1037/0021-843X.107.3.508

Favrole, P., Jehel, L., Levy, P., Descombes, S., Muresan, I.-P., Manifacier, M.-J., \& Alamowitch, S. (2013). Frequency and predictors of post-traumatic stress disorder 
after stroke: a pilot study. Journal of the Neurological Sciences, 327(1-2), 35-40.

https://doi.org/10.1016/j.jns.2013.02.001

Friedman, M. J. (2013). Finalizing PTSD in DSM-5: Getting here from there and where to go next. Journal of Traumatic Stress, 26(5), 548-56. https://doi.org/10.1002/jts.21840

Friedman, M. J., Resick, P. A., Bryant, R. A., \& Brewin, C. R. (2011). Considering PTSD for DSM-5.Depression and Anxiety, 28(9), 750-69. https://doi.org/10.1002/da.20767

Gandubert, C., Scali, J., Ancelin, M.-L., Carrière, I., Dupuy, A.-M., Bagnolini, G., ... Chaudieu, I. (2016). Biological and psychological predictors of posttraumatic stress disorder onset and chronicity. A one-year prospective study. Neurobiology of Stress, 3, 61-67. https://doi.org/10.1016/j.ynstr.2016.02.002

Gold, S. D., Marx, B. P., Soler-Baillo, J. M., \& Sloan, D. M. (2005). Is life stress more traumatic than traumatic stress? Journal of Anxiety Disorders, 19(6), 687-98. https://doi.org/10.1016/j.janxdis.2004.06.002

Guardia, D., Brunet, A., Duhamel, A., Ducrocq, F., Demarty, A.-L., \& Vaiva, G. (2013). Prediction of trauma-related disorders: a proposed cutoff score for the peritraumatic distress inventory. The Primary Care Companion for CNS Disorders, 15(1).

https:/doi.org/10.4088/PCC.12101406

Hargrave, P. A., Leathem, J. M., \& Long, N. R. (2012). Peritraumatic distress: Its relationship to posttraumatic stress and complicated grief symptoms in sudden death survivors.

Journal of Traumatic Stress, 25(3), 344-7. https://doi.org/10.1002/jts.21703

Hetzel-Riggin, M. D., \& Meads, C. L. (2016). Interrelationships among three avoidant coping styles and their relationship to trauma, peritraumatic distress, and posttraumatic stress disorder. Journal of Nervous and Mental Disease, 204(2), 123-131.

https://doi.org/10.1097/NMD.0000000000000434 
Hiar, S., Thomas, C. L., Hinton, D. E., Salles, J., Goutaudier, N., Olliac, B., \& Bui, E. (2016). Somatic symptoms mediate the relationship between trauma during the Arab Spring and quality of life among Tunisians. Journal of Nervous and Mental Disease, 204(2),

153-155. https://doi.org/10.1097/NMD.0000000000000446

Inslicht, S.S., McCaslin, S. E., Metzler, T. J., Henn-Haase, C., Hart, S. L., Maguen, S., ... Marman, C. R. (2010). Family psychiatric history, peritraumatic reactivity, and posttraumatic stress symptoms: a prospective study of police. Journal of Psychiatric Resedrch, 44(1), 22-31. https://doi.org/10.1016/j.jpsychires.2009.05.011

Jehel, L., Brunet, A., Paterniti, S., \& Guelfi, J. (2005). Validation de la version française de l'inventaire de détresse péritraumatique. Canadian Journal of Psychiatry, 50(1).

Jehel, L., Paterniti, S., Brunet, A., Louville, P., \& Guelfi, J.-D. (2006). L’intensité de la détresse péritraumatique prédit la survenue des symptômes post-traumatiques parmi des victimes d'agressions. L'Encéphale, 32(6, Part 1), 953-956.

https://doi.org/10.1016/S0013-7006(06)76272-8

Kawashima, Y., Nishi, D., Noguchi, H., Usuki, M., Yamashita, A., Koido, Y., ... Matsuoka, Y.J. (2016). Post-traumatic stress symptoms and burnout among medical rescue workers 4 years after the Great East Japan Earthquake: A longitudinal study. Disaster Medicine and Public Health Preparedness, 10(6), 848-853.

https://doi.org/10.1017/dmp.2016.83

Kilpatrick, D. G., Resnick, H. S., Freedy, J. R., Pelcovitz, D., Resick, P., Roth, S., \& van der Kolk, B. (1998). Posttraumatic stress disorder field trial: Evaluation of the PTSD construct-Criteria A through E. In T. A. Widiger, A. J. Frances, H. A. Pincus, R. Ross, M. B. First, W. Davis, \& M. Kline (Eds.), DSM-IV sourcebook (Vol. 4, pp. 803-844). Washington D.C.: American Psychiatric Association. 
Kuhn, E., Blanchard, E. B., Fuse, T., Hickling, E. J., \& Broderick, J. (2006). Heart rate of motor vehicle accident survivors in the emergency department, peritraumatic psychological reactions, ASD, and PTSD severity: A 6-month prospective study. Journal of Traumatic Stress, 19(5), 735-40. https://doi.org/10.1002/jts.20150

Kunst, M.J. (2010). Peritraumatic distress, posttraumatic stress disorder symptoms, and posttraumatic growth in victims of violence. Journal of Traumatic Stress, 23(4), 514 8. https:/doi.org/10.1002/jts.20556

Kunst, M.J.(2012). Recalled peritraumatic distress in survivors of violent crime: Exploring its impact on the relationship between posttraumatic stress disorder symptoms and posttraumatic growth. Journal of Nervous and Mental Disease, 200(11), 962-6. https://doi.org/10.1097/NMD.0b013e3182718a74

Kunst, M. J. J., \& Koster, N. N. (2016). Psychological distress following crime victimization: An exploratory study from an agency perspective. Stress and Health, 33(4), 405-414. https://doi.org/10.1002/smi.2725

Kunst, M. J. J., Rutten, S., \& Knijf, E. (2013). Satisfaction with the initial police response and development of posttraumatic stress disorder symptoms in victims of domestic burglary. Journal of Traumatic Stress, 26(1), 111-118. https://do1.org/10.1002/jts.21774

Kunst, M. J., Winkel, F. W., \& Bogaerts, S. (2011). Posttraumatic anger, recalled peritraumatic emotions, and PTSD in victims of violent crime. Journal of Interpersonal Violence, 26(17), 3561-3579.

https://doi.org/10.1177/0886260511403753

Lacy, J. W., \& Stark, C. E. L. (2013). The Neuroscience of Memory: Implications for the Courtroom. Nature Reviews. Neuroscience, 14(9), 649-658. https://doi.org/10.1038/nrn3563 
Ladois-Do Pilar Rei, A., Bui, E., Bousquet, B., Simon, N. M., Rieu, J., Schmitt, L., ...

Birmes, P. (2012). Peritraumatic reactions and posttraumatic stress disorder symptoms after psychiatric admission. The Journal of Nervous and Mental Disease, 200(1), 88-

90-https./doi.org/10.1097/NMD.0b013e31823fafb9

Lavoie, S., Talbot, L. R., Mathieu, L., Dallaire, C., Dubois, M.-F., \& Courcy, F. (2015). An exploration of factors associated with post-traumatic stress in ER nurses. Journal of Nursing Management, 24(2), 174-183. https://doi.org/10.1111/jonm.12294

Lehman, H.(1985). Somatic and psychological symptoms after the experience of life threatening events: A profile analysis. Victimology, 10, 512-538.

Letamendia, C., Leblanc, N. J., Pariente, J., Simon, N. M., Thomas, C. L., Chabrol, H., ... But, E. (2012). Peritraumatic distress predicts acute posttraumatic stress disorder symptoms after a first stroke. General Hospital Psychiatry, 34(5), e11-13. https://doi.org/10.1016/j.genhosppsych.2012.03.011

Lewis, G. C., Platts-Mills, T. F., Liberzon, I., Bair, E., Swor, R., Peak, D., .. McLean, S. A. (2014). Incidence and predictors of acute psychological distress and dissociation after motor vehicle collision: a cross-sectional study. Journal of Trauma \& Dissociation:

The Official Journal of the International Society for the Study of Dissociation (ISSD), 15(5), 527-547. https://doi.org/10.1080/15299732.2014.908805

Lilly, M. M., London, M. J., \& Mercer, M. C. (2016). Predictors of obesity and physical health complaints among 911 telecommunicators. Safety and Health at Work, 7(1), 55-62. https://doi.org/10.1016/j.shaw.2015.09.003

Maia, D. B., Marmar, C. R., Henn-Haase, C., Nóbrega, A., Fiszman, A., Marques-Portella, C., Figueira, I. (2011). Predictors of PTSD symptoms in brazilian police officers: the synergy of negative affect and peritraumatic dissociation. Revista Brasileira De Psiquiatria (Sao Paulo, Brazil: 1999), 33(4), 362-366. 
March, J. S. (1993). What constitutes a stressor? The "criterion A" issue. In J. R. T. Davidson \& E. B. Foa (Eds.), Posttraumatic Stress Disorder: DSM-IV and Beyond (pp. 37-54). Washington D.C.: American Psychiatric Press.

McCaslin, S. E., de Zoysa, P., Butler, L. D., Hart, S., Marmar, C. R., Metzler, T. J., \& Koopman, C. (2009). The relationship of posttraumatic growth to peritraumatic reactions and posttraumatic stress symptoms among Sri Lankan university students. Journal of Traumatic Stress, 22(4), 334-339. https://doi.org/10.1002/jts.20426

Meister, R.E. Princip, M., Schnyder, U., Barth, J., Znoj, H., Schmid, J.-P., ... von Känel, R. (2016). Association of trait resilience with peritraumatic and posttraumatic stress in patients with myocardial infarction. Psychosomatic Medicine, 78(3), 327-334.

https://doi.org/10.1097/PSY.0000000000000278

Moss, K. M., Simcock, G., Cobham, V., Kildea, S., Elgbeili, G., Laplante, D. P., \& King, S. (2017). A potential psychological mechanism linking disaster-related prenatal maternat stress with child cognitive and motor development at 16 months: The QF2011 Queensland Flood Study. Developmental Psychology, 53(4), 629-641. https://doi.org/10.1037/dev0000272

Mutabaruka, J., Séjourné, N., Bui, E., Birmes, P., \& Chabrol, H. (2012). Traumatic grief and traumatic stress in survivors 12 years after the genocide in Rwanda. Stress \& Health, 28(4), 289-96. https://doi.org/10.1002/smi.1429

Neylan, T. C., Brunet, A., Pole, N., Best, S. R., Metzler, T. J., Yehuda, R., \& Marmar, C. R. (2005). PTSD symptoms predict waking salivary cortisol levels in police officers. Psychoneuroendocrinology, 30(4), 373-381. https://doi.org/10.1016/j.psyneuen.2004.10.005

Nishi, D., Kawashima, Y., Noguchi, H., Usuki, M., Yamashita, A., Koido, Y., \& Matsuoka, Y. J. (2016). Resilience, post-traumatic growth, and work engagement among health 
care professionals after the Great East Japan Earthquake: A 4-year prospective follow-up study. Journal of Occupational Health, 58(4), 347-353.

\footnotetext{
https://doi.org/10.1539/joh.16-0002-OA
}

Nishi, D., Matsuoka, Y., Noguchi, H., Sakuma, K., Yonemoto, N., Yanagita, T., ... Kim, Y. (2009). Reliability and validity of the Japanese version of the Peritraumatic Distress Inventory. General Hospital Psychiatry, 31(1), 75-9.

https://oi.org/10.1016/j.genhosppsych.2008.09.002

Nishi, D., Matsuoka, Y., Yonemoto, N., Noguchi, H., Kim, Y., \& Kanba, S. (2010).

Peritraumatic Distress Inventory as a predictor of post-traumatic stress disorder after a severe motor vehicle accident. Psychiatry and Clinical Neuroscience, 64(2), 149-56.

https://doi.org/10.1111/j.1440-1819.2010.02065.x

O’Donnell, M. L., Creamer, M., McFarlane, A. C., Silove, D., \& Bryant, R. A. (2010).

Should A2 be a diagnostic requirement for posttraumatic stress disorder in DSM-V?

Psychiatry Research, 176(2-3), 257-260.

https://doi.org/10.1016/j.psychres.2009.05.012

Olde, E., van der Hart, O., Kleber, R., \& van Son, M. (2006). Posttraumatic stress following childbirth. A review. Clinical Psychology Review, 26(1), 1-16.

https://doi.org/10.1016/j.cpr.2005.07.002

Otis, C., Marchand, A., \& Courtois, F. (2012). Peritraumatic dissociation as a mediator of peritraumatic distress and PTSD: A retrospective, cross-sectional study. Journal of Trauma \& Dissociation: The Official Journal of the International Society for the Study of Dissociation (ISSD), 13(4), 469-477.

https://doi.org/10.1080/15299732.2012.670870 
Pai, A., Suris, A. M., \& North, C. S. (2017). Posttraumatic Stress Disorder in the DSM-5:

Controversy, Change, and Conceptual Considerations. Behavioral Sciences (Basel,

Switzerland), 7(1). https://doi.org/10.3390/bs 7010007

Pereira, G-F., McLean, S. A., Tkacik, T. J., Swor, R. A., Jones, J. S., Lee, D. C., ... Platts-

Mills, T. F. (2014). Pain, distress, and anticipated recovery for older versus younger

emergency department patients after motor vehicle collision. BMC Emergency

Medicine, 14, 25. https://doi.org/10.1186/s12873-014-0025-y

Pierce, H., \& Lilly, M. M. (2012). Duty-related trauma exposure in 911 telecommunicators:

Considering the risk for posttraumatic stress. Journal of Traumatic Stress, 25(2), 211-

5. https://doi.org/10.1002/jts.21687

RDoC Matrix. (2017). National Institute of Mental Health. Retrieved from

https://www.nimh.nih.gov/research-priorities/rdoc/constructs/rdoc-matrix.shtml

Resnick, H. S. (1997). Acute panic reactions among rape victims: Implications for prevention of postrape psychopathology. National Center for PTSD Clinical Quarterly, 7, 41-45.

Rodgers, R. F., Franko, D. L., Brunet, A., Herbert, C. F., \& Bui, E. (2012). Disordered eating following exposure to television and internet coverage of the March 2011 Japan

earthquake. International Journal of Eating Disorders, 45(7), 845-9.

https://doi.org/10.1002/eat.22031

Roemer, L.,Litz, B. T., Orsillo, S. M., Ehlich, P. J., \& Friedman, M. J. (1998). Increases in retrospective accounts of war-zone exposure over time: The role of PTSD symptom severity. Journal of Traumatic Stress, 11(3), 597-605.

https://doi.org/10.1023/A:1024469116047

Rose, S., Bisson, J., Churchill, R., \& Wessely, S. (2002). Psychological debriefing for preventing post traumatic stress disorder (PTSD). The Cochrane Database of Systematic Reviews, (2), CD000560. https://doi.org/10.1002/14651858.CD000560 
Schnurr, P. P., Spiro, A., III, Vielhauer, M. J., Findler, M. N., \& Hamblen, J. L. (2002).

Trauma in the lives of older men: Findings from the Normative Aging Study. Journal of Clinical Geropsychology, 8(3), 175-187.

Shalev, A.Y., Sahar, T., Freedman, S., Peri, T., Glick, N., Brandes, D., ... Pitman, R. K.

(1998). A prospective study of heart rate response following trauma and the subsequent development of posttraumatic stress disorder. Archives of General Psychiatry, 55(6), 553-559.

Shigemura, J. Tanigawa, T., Nishi, D., Matsuoka, Y., Nomura, S., \& Yoshino, A. (2014). Associations between disaster exposures, peritraumatic distress, and posttraumatic stress responses in Fukushima nuclear plant workers following the 2011 Nuclear Accident: The Fukushima NEWS Project Study. PLoS ONE, 9(2).

https://do1.org/10.1371/journal.pone.0087516

Simeon, D., Greenberg, J., Knutelska, M., Schmeidler, J., \& Hollander, E. (2003).

Peritraumatic reactions associated with the World Trade Center disaster. American Journal of Psychiatry, 160(9), 1702-1705.

https://doi.org/10.1176/appi.ajp.160.9.1702

Simeon, D., Greenberg, J., Nelson, D., Schmeidler, J., \& Hollander, E. (2005). Dissociation and posttraumatic stress 1 year after the World Trade Center disaster: follow-up of a longitudinal survey. The Journal of Clinical Psychiatry, 66(2), 231-237.

Simeon,D., Yehuda, R., Knutelska, M., \& Schmeidler, J. (2008). Dissociation versus posttraumatic stress: cortisol and physiological correlates in adults highly exposed to the World Trade Center attack on 9/11. Psychiatry Research, 161(3), 325-329. https://doi.org/10.1016/j.psychres.2008.04.021 
Solomon, Z., Laor, N., \& McFarlane, A. C. (1996). Acute posttraumatic reactions in soldiers and civilians. In Traumatic stress: The effects of overwhelming experience on mind, body, and society. (pp. 102-114). New York, NY, US: Guilford Press.

Sugar, J., \& Ford,J. D. (2012). Peritraumatic reactions and posttraumatic stress disorder in psychiatrically impaired youth. Journal of Traumatic Stress, 25(1), 41-49. https://oi.org/10.1002/jts.21668

Tanisho, Y., Shigemura, J., Kubota, K., Tanigawa, T., Bromet, E. J., Takahashi, S., ... Fukushima NEWS Project Collaborators. (2016). The longitudinal mental health impact of Fukushima nuclear disaster exposures and public criticism among power plant workers: the Fukushima NEWS Project study. Psychological Medicine, 46(15), 3117-3125. https://doi.org/10.1017/S003329171600194X

Thomas, E., Saumier, D., \& Brunet, A. (2012). Peritraumatic distress and the course of posttraumatic stress disorder symptoms: A meta-analysis. Canadian Journal of Psychiatry, 57(2), 122-9. https://doi.org/10.1177/070674371205700209

Tucker, P., Dickson, W., Pfefferbaum, B., McDonald, N. B., \& Allen, G. (1997). Traumatic reactions as predictors of posttraumatic stress six months after the Oklahoma City bombing. Psychiatric Services (Washington, D.C.), 48(9), 1191-1194. https://do1.org/10.1176/ps.48.9.1191

von Känel, R., Hari, R., Schmid, J.-P., Saner, H., \& Begré, S. (2011). Distress related to myocardial infarction and cardiovascular outcome: a retrospective observational study. BMC Psychiatry, 11, 98. https://doi.org/10.1186/1471-244X-11-98

Wiedemar, L., Schmid, J.-P., Müller, J., Wittmann, L., Schnyder, U., Saner, H., \& von Känel, R. (2008). Prevalence and predictors of posttraumatic stress disorder in patients with acute myocardial infarction. Heart \& Lung: The Journal of Critical Care, 37(2), 113121. https://doi.org/10.1016/j.hrtlng.2007.03.005 


\begin{tabular}{|c|c|c|c|c|c|c|c|}
\hline $\begin{array}{l}\text { Author/D } \\
\text { ate }\end{array}$ & $\mathrm{N}$ & Sample & $\begin{array}{l}\text { DSM- } \\
5 \\
\text { Criteri } \\
\text { on A } \\
\text { Met }\end{array}$ & $\begin{array}{l}\text { Time } \\
\text { between } \\
\text { Trauma } \\
\text { and PDI } \\
\text { Assessm } \\
\text { ent }\end{array}$ & $\begin{array}{l}\text { Time } \\
\text { between } \\
\text { Trauma } \\
\text { and } \\
\text { Outcome } \\
\text { Assessm } \\
\text { ent }\end{array}$ & $\begin{array}{l}\text { PTSD } \\
\text { Outcomes }\end{array}$ & $\begin{array}{l}\text { Other } \\
\text { Outcomes }\end{array}$ \\
\hline
\end{tabular}

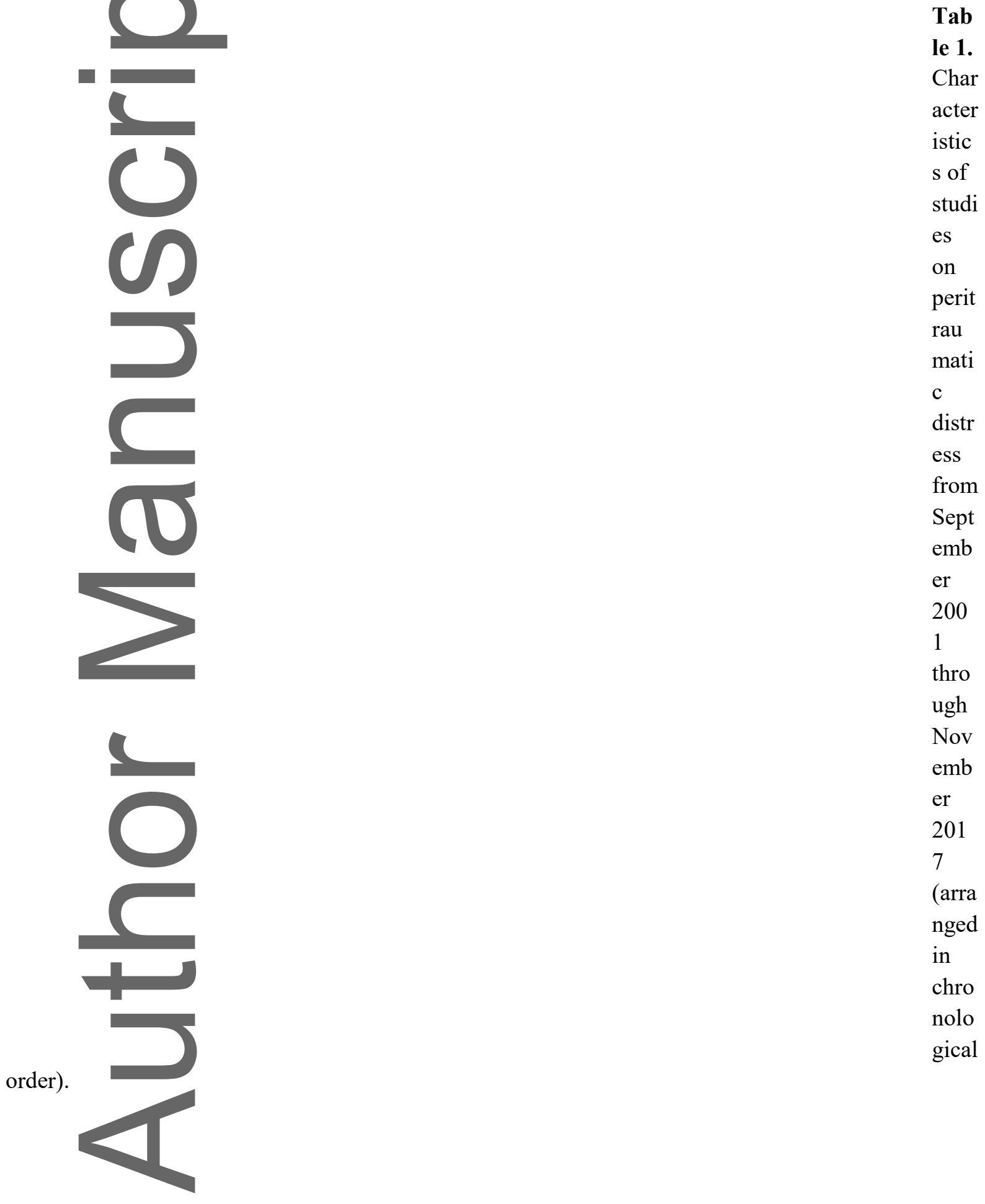

This article is protected by copyright. All rights reserved. 


\begin{tabular}{|c|c|c|c|c|c|c|}
\hline $\begin{array}{l}\text { Brunet et } \\
\text { al., } 2001\end{array}$ & 702 & $\begin{array}{l}\text { Police officers } \\
\text { exposed to a } \\
\text { range of } \\
\text { critical } \\
\text { incidents }\end{array}$ & Yes & $\begin{array}{l}\text { Mean } \\
(\mathrm{SD})= \\
6.64 \\
(5.16) \\
\text { years }\end{array}$ & $\begin{array}{l}\text { Mean } \\
(\mathrm{SD})= \\
6.64 \\
(5.16) \\
\text { years }\end{array}$ & $\begin{array}{l}\text { CMS: } r= \\
0.46^{* * *} \\
\text { IES-R, } \\
\quad \text { Intrusion: } r \\
=0.47^{* * *} \\
\quad \text { Avoidance: } \\
r=0.47^{* * *} \\
\\
\text { Hyperarousal: } \\
r=0.42^{* * *}\end{array}$ \\
\hline $\begin{array}{l}\text { Simeon et } \\
\text { al., } 2003\end{array}$ & 75 & $\begin{array}{l}\text { Adults } \\
\text { significantly } \\
\text { affected by the } \\
\text { World Trade } \\
\text { Center attacks }\end{array}$ & Mixed & $\begin{array}{l}\leq 3 \\
\text { months }\end{array}$ & $\begin{array}{l}\leq 3 \\
\text { months }\end{array}$ & $\begin{array}{l}\text { Using factor } \\
\text { analyses, } 4 \\
\text { distress factor } \\
\text { subscales of } \\
\text { the PDI were } \\
\text { identified (life } \\
\text { threat, loss of } \\
\text { control, } \\
\text { helplessness/a } \\
\text { nger, } \\
\text { guilt/shame). } \\
\text { In a regression } \\
\text { analysis, } \\
\text { PTSD } \\
\text { symptoms } \\
\text { (IES-R) were } \\
\text { predicted by } \\
\text { loss of control } \\
(\beta=0.53, \\
\text { corrected } F= \\
8.44, d f=5, \\
68, p<0.001) \\
\text { and } \\
\text { helplessness/a } \\
\text { nger }(\beta=0.35, \\
\text { corrected } F= \\
3.46, d f=5, \\
68, p<0.01) . \\
\\
\text { Re- } \\
\text { experiencing } \\
\text { was predicted } \\
\text { by } \\
\text { helplessness/a } \\
\text { nger }(\beta=0.30, \\
\text { corrected } F= \\
4.43, d f=5, \\
68, p<0.01) . \\
\text { Avoidance } \\
\text { was predicted } \\
\text { by loss of } \\
\text { control ( } \beta= \\
0.45, \text { corrected } \\
F=3.98, \text { df }= \\
5,68, p< \\
0.01) . \\
\text {. }\end{array}$ \\
\hline
\end{tabular}




\begin{tabular}{|c|c|c|c|c|c|c|c|}
\hline & & & & & & $\begin{array}{l}\text { Arousal was } \\
\text { predicted by } \\
\text { life threat }(\beta= \\
0.41, \text { corrected } \\
F=3.94, d f= \\
5,68, p< \\
0.01) .\end{array}$ & \\
\hline $\begin{array}{l}\text { Birmes et } \\
\text { al., } 2005\end{array}$ & 200 & $\begin{array}{l}\text { Individuals } \\
\text { after a factory } \\
\text { explosion }\end{array}$ & Mixed & 6 months & 6 months & $\begin{array}{l}\text { PCL: } r= \\
0.67 * * * \\
\text { In a } \\
\text { hierarchical } \\
\text { multiple linear } \\
\text { regression, } \\
\text { peritraumatic } \\
\text { distress } \\
\text { predicted PCL } \\
\text { scores even } \\
\text { after } \\
\text { controlling for } \\
\text { peritraumatic } \\
\text { dissociation }(\beta \\
\left.=0.48^{* * *}\right) \text {. }\end{array}$ & \\
\hline $\begin{array}{l}\text { Jehel et } \\
\text { al., } 2005\end{array}$ & 127 & $\begin{array}{l}\text { Individuals } \\
\text { after assault }\end{array}$ & Yes & $<1$ year & $<$ lyear & $\begin{array}{l}\text { IES-R: } r= \\
0.63^{*}\end{array}$ & \\
\hline $\begin{array}{l}\text { Neylan et } \\
\text { al., } 2005\end{array}$ & $\begin{array}{l}30 \\
\text { (subpopula } \\
\text { tion from } \\
\text { Brunet et } \\
\text { al., 2001) }\end{array}$ & $\begin{array}{l}\text { Active duty } \\
\text { police officers }\end{array}$ & Yes & $\begin{array}{l}\text { Not } \\
\text { reported }\end{array}$ & $\begin{array}{l}\text { Not } \\
\text { reported }\end{array}$ & $\begin{array}{l}\text { PCL: } r= \\
0.43^{*}\end{array}$ & \\
\hline $\begin{array}{l}\text { Simeon et } \\
\text { al., } 2005\end{array}$ & - & $\begin{array}{l}\text { Adults } \\
\text { significantly } \\
\text { affected by the } \\
\text { World Trade } \\
\text { Center attacks }\end{array}$ & Mixed & $\begin{array}{l}<3 \\
\text { months }\end{array}$ & 1 year & $\begin{array}{l}\text { IES-R: } r= \\
0.51 * * *\end{array}$ & \\
\hline $\begin{array}{l}\text { Jehel et } \\
\text { al., } 2006\end{array}$ & 63 & $\begin{array}{l}\text { Individuals } \\
\text { after assault }\end{array}$ & Yes & $\leq 1$ year & $\begin{array}{l}\leq 1 \text { year; } \\
6 \text { months } \\
\text { after } \\
\text { initial } \\
\text { assessme } \\
\text { nt }\end{array}$ & $\begin{array}{l}\text { IES-R, FU: } r= \\
0.63^{* *}\end{array}$ & \\
\hline $\begin{array}{l}\text { Kuhn et } \\
\text { al., } 2006\end{array}$ & 50 & $\begin{array}{l}\text { Individuals } \\
\text { after MVC }\end{array}$ & Yes & 2 weeks & $\begin{array}{l}\text { BL: } 2 \\
\text { weeks } \\
\text { FU1: } 1 \\
\text { month } \\
\text { FU2: } 3 \\
\text { months } \\
\text { FU3: } 6 \\
\text { months }\end{array}$ & $\begin{array}{l}\text { CAPS, } 1 \\
\text { month: } r= \\
0.27 * * * \\
\quad 3 \\
\text { months: } r= \\
0.22 \\
\quad 6 \\
\text { months: } r= \\
0.22 \quad 3 \\
\text { PCL, } 1 \text { month: } \\
r=0.31 * * * \\
\quad 3 \\
\text { months: } r= \\
0.30^{* *} \\
\quad 6 \\
\text { months: } r= \\
0.07\end{array}$ & $\begin{array}{l}\text { ASD Interview, } \\
2 \text { weeks: } \\
r=0.55^{* *} \\
\text { ASD Scale, } 2 \\
\text { weeks: } \\
r=0.56^{* *}\end{array}$ \\
\hline
\end{tabular}




\begin{tabular}{|c|c|c|c|c|c|c|c|}
\hline $\begin{array}{l}\text { Boudou } \\
\text { et al., } \\
2007\end{array}$ & 117 & $\begin{array}{l}\text { Women after } \\
\text { childbirth }\end{array}$ & No & $<1$ week & $\begin{array}{l}1 \text { day, } 6 \\
\text { weeks }\end{array}$ & $\begin{array}{l}\text { IES-R, FU: } r= \\
0.39^{*}\end{array}$ & \\
\hline $\begin{array}{l}\text { Dickie et } \\
\text { al., } 2008\end{array}$ & 27 & $\begin{array}{l}\text { Individuals } \\
\text { with PTSD } \\
\text { after mixed } \\
\text { trauma }\end{array}$ & Yes & $\begin{array}{l}5-62 \\
\text { weeks, } \\
\text { mean } \\
(\mathrm{SD})= \\
16(12) \\
\text { weeks }\end{array}$ & $\begin{array}{l}5-62 \\
\text { weeks, } \\
\text { mean } \\
(\mathrm{SD})= \\
16(12) \\
\text { weeks }\end{array}$ & $\begin{array}{l}\text { PDI did not } \\
\text { mediate the } \\
\text { relationship } \\
\text { between } \\
\text { memory } \\
\text { performance } \\
\text { and PTSD } \\
\text { symptoms } \\
\text { (CAPS). }\end{array}$ & \\
\hline $\begin{array}{l}\text { Simeon et } \\
\text { al., } 2008\end{array}$ & 21 & $\begin{array}{l}\text { Individuals } \\
\text { highly } \\
\text { exposed to } \\
\text { 9/11 World } \\
\text { Trade Center } \\
\text { attack }\end{array}$ & Yes & $\begin{array}{l}\text { Mean }= \\
9 \text { months }\end{array}$ & $\begin{array}{l}\text { Mean }= \\
9 \text { months }\end{array}$ & $\begin{array}{l}\text { CAPS: } r= \\
0.49^{*}\end{array}$ & $\begin{array}{l}\text { Dissociation, } \\
\text { DES: not } \\
\text { significantly } \\
\text { associated with } \\
\text { PDI }\end{array}$ \\
\hline $\begin{array}{l}\text { McCaslin } \\
\text { et al., } \\
2009\end{array}$ & 93 & $\begin{array}{l}\text { Sri Lankan } \\
\text { university } \\
\text { students who } \\
\text { experienced a } \\
\text { traumatic life } \\
\text { event }\end{array}$ & Yes & Variable & Variable & $\begin{array}{l}\text { PCL-S: } r= \\
0.49^{* * *}\end{array}$ & $\begin{array}{l}\text { Posttraumatic } \\
\text { Growth, PTGI: } \\
r=0.10\end{array}$ \\
\hline $\begin{array}{l}\text { Nishi et } \\
\text { al., } 2009\end{array}$ & 135 & $\begin{array}{l}\text { Individuals } \\
\text { after MVC }\end{array}$ & Yes & Variable & Variable & $\begin{array}{l}\text { IES-R: } r= \\
0.67^{* *}\end{array}$ & $\begin{array}{l}\text { Anxiety/Depres } \\
\text { sion, HADS, } \\
\quad \text { Total: } r \\
=0.47^{* *} \\
\text { Anxiety: } r= \\
0.49^{* *} \\
\text { Depression: } r= \\
0.36^{* *}\end{array}$ \\
\hline $\begin{array}{l}\text { Allenou } \\
\text { et al., } \\
2010\end{array}$ & 100 & $\begin{array}{l}72 \text { mothers } \\
\text { and } 28 \text { fathers } \\
\text { after children } \\
\text { experienced } \\
\text { MVC }\end{array}$ & Yes & 1 week & 5 weeks & $\begin{array}{l}\text { In mothers: } \\
\text { PCL: } r= \\
0.34^{* *} \\
\text { In fathers: } \\
\text { PCL: } r=0.33\end{array}$ & \\
\hline $\begin{array}{l}\text { Bui et al., } \\
2010\end{array}$ & 25 & $\begin{array}{l}\text { Adults older } \\
\text { than } 65 \text { after } \\
\text { traffic } \\
\text { accident or } \\
\text { violent assault }\end{array}$ & Yes & $\leq 1$ week & 1 month & $\begin{array}{l}\text { CAPS: } r= \\
0.60^{* *} \\
\text { In a multiple } \\
\text { regression } \\
\text { analysis, PDI } \\
\text { at BL } \\
\text { predicted } \\
\text { PTSD } \\
\text { symptoms at } \\
\text { FU even after } \\
\text { controlling for } \\
\text { peritraumatic } \\
\text { dissociation }(\beta \\
\left.=0.78^{* *}\right) .\end{array}$ & \\
\hline $\begin{array}{l}\text { Bui et al., } \\
2010\end{array}$ & 103 & $\begin{array}{l}\text { Children, aged } \\
8 \text { to } 15 \text { years, } \\
\text { admitted to }\end{array}$ & Yes & $\leq 1$ week & 5 weeks & $\begin{array}{l}\text { CAPS-CA: } r= \\
0.40^{*} \\
\text { CPTS-RI: } r=\end{array}$ & \\
\hline
\end{tabular}

This article is protected by copyright. All rights reserved. 


\begin{tabular}{|c|c|c|c|c|c|c|c|}
\hline & 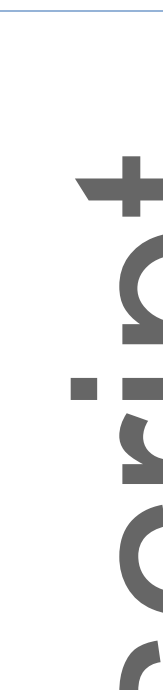 & $\begin{array}{l}\text { emergency } \\
\text { department } \\
\text { after a road } \\
\text { traffic } \\
\text { accident } \\
\\
\end{array}$ & & & & $\begin{array}{l}0.57^{*} \\
\text { In two } \\
\text { hierarchal } \\
\text { linear } \\
\text { regressions, } \\
\text { PDI predicted } \\
\text { both CPTS-RI } \\
\left(\beta=0.51^{* *}\right) \\
\text { and CAPS-CA } \\
\left(\beta=0.33^{* *}\right) \\
\text { after } \\
\text { controlling for } \\
\text { age, gender, } \\
\text { and } \\
\text { peritraumatic } \\
\text { dissociation. }\end{array}$ & \\
\hline $\begin{array}{l}\text { Inslicht et } \\
\text { al., } 2010\end{array}$ & 278 & Police officers & Yes & $\leq 1$ year & $<1$ year & $\begin{array}{l}\text { PCL-S: } r= \\
0.44^{* * *}\end{array}$ & $\begin{array}{l}\text { In path } \\
\text { analyses, PDI } \\
\text { mediated the } \\
\text { relationship } \\
\text { between family } \\
\text { history of mood } \\
\text { and anxiety } \\
\text { disorders and } \\
\text { PTSD } \\
\text { symptoms. } \\
\text { PDI also } \\
\text { mediated the } \\
\text { relationship } \\
\text { between a } \\
\text { family history } \\
\text { of drug and } \\
\text { alcohol use } \\
\text { disorders and } \\
\text { PTSD } \\
\text { symptoms. }\end{array}$ \\
\hline $\begin{array}{l}\text { Kunst, } \\
2010\end{array}$ & $\begin{array}{l}678(\mathrm{BL}) \\
205(\mathrm{FU})\end{array}$ & $\begin{array}{l}\text { rvivors of } \\
\text { lence }\end{array}$ & Yes & $\begin{array}{l}\text { Mean } \\
(\mathrm{SD})= \\
4.9(3.7) \\
\text { years }\end{array}$ & $\begin{array}{l}\text { Mean } \\
(\mathrm{SD})= \\
5.4(4.8) \\
\text { years }\end{array}$ & & $\begin{array}{l}\text { In a } \\
\text { multivariate } \\
\text { regression } \\
\text { analysis } \\
\text { controlling for } \\
\text { a number of } \\
\text { variables, } \\
\text { including time } \\
\text { since trauma, } \\
\text { PTSD } \\
\text { symptoms, age, } \\
\text { and sex, } \beta= \\
0.25^{* * *} \text { for } \\
\text { linear } \\
\text { relationship } \\
\text { between BL } \\
\text { PTGI and PDI } \\
\text { and } \beta=0.20^{*} \\
\text { for linear } \\
\text { relationship } \\
\text { between FU }\end{array}$ \\
\hline
\end{tabular}

This article is protected by copyright. All rights reserved. 


\begin{tabular}{|c|c|c|c|c|c|c|c|}
\hline & & & & & & & PTGI and PDI. \\
\hline $\begin{array}{l}\text { Nishi et } \\
\text { al., } 2010\end{array}$ & 79 & $\begin{array}{l}\text { Individuals } \\
\text { after MVC }\end{array}$ & Yes & $\begin{array}{l}0-23 \\
\text { days }\end{array}$ & $\begin{array}{l}\text { Mean }= \\
37 \text { days }\end{array}$ & $\begin{array}{l}\text { In a univariate } \\
\text { regression } \\
\text { analysis, PDI } \\
\text { predicted IES- } \\
\mathrm{R}(\beta= \\
\left.0.61^{* * *}\right) \text {. } \\
\text { In a } \\
\text { multivariate } \\
\text { regression } \\
\text { analysis, PDI } \\
\text { predicted IES- } \\
\mathrm{R}\left(\beta=0.49^{* *}\right) \\
\text { after } \\
\text { controlling for } \\
\text { age, family } \\
\text { history, } \\
\text { psychiatric } \\
\text { history, } \\
\text { education, } \\
\text { heart rate, } \\
\text { injury } \\
\text { severity, and } \\
\text { sex. }\end{array}$ & \\
\hline $\begin{array}{l}\text { O'Donnel } \\
\text { I et al., } \\
2010\end{array}$ & 535 & $\begin{array}{l}\text { Individuals } \\
\text { hospitalized } \\
\text { after trauma } \\
\text { injury }\end{array}$ & Yes & $\begin{array}{l}\text { During } \\
\text { admissio } \\
\mathrm{n}, \text { mean } \\
(\mathrm{SD})= \\
7.99 \\
(10.13) \\
\text { days } \\
\text { after } \\
\text { injury }\end{array}$ & 3 months & $\begin{array}{l}\text { Patients who } \\
\text { developed } \\
\text { PTSD per } \\
\text { CAPS at } 3 \text { - } \\
\text { month follow- } \\
\text { up had } \\
\text { significantly } \\
\text { higher PDI } \\
\text { total scores, }(t \\
=2.83, d f= \\
533, p= \\
0.005, d= \\
0.48) \text { than } \\
\text { those who did } \\
\text { not. }\end{array}$ & \\
\hline $\begin{array}{l}\text { Apfel et } \\
\text { al., } 2011\end{array}$ & 243 & Police officers & Mixed & $<1$ year & $<1$ year & $\begin{array}{l}\text { Transformed } \\
\text { PCL, } \\
\text { Total: } r \\
=0.45^{* *} \\
\text { Re- } \\
\text { experiencing: } \\
r=0.38^{* *} \\
\text { Avoidance: } r \\
=0.40^{* *} \\
\text { Hyperarousal: } \\
r=0.38^{* *}\end{array}$ & $\begin{array}{l}\text { PDI mediated } \\
\text { the relationship } \\
\text { between } \\
\text { salivary 3- } \\
\text { methoxy-4- } \\
\text { hydroxy- } \\
\text { phenylglycol } \\
\text { (MHPG) levels } \\
\text { after recovery } \\
\text { to laboratory } \\
\text { stressor } \\
\text { exposure and } \\
\text { development of } \\
\text { PTSD } \\
\text { symptoms a } \\
\text { year after a } \\
\text { critical } \\
\text { incident. }\end{array}$ \\
\hline
\end{tabular}




\begin{tabular}{|c|c|c|c|c|c|c|}
\hline $\begin{array}{l}\text { Bui et al., } \\
2011\end{array}$ & 133 & $\begin{array}{l}\text { Children, aged } \\
8 \text { to } 15 \text { years, } \\
\text { admitted to } \\
\text { the emergency } \\
\text { department } \\
\text { after a road } \\
\text { traffic } \\
\text { accident }\end{array}$ & Yes & $<1$ week & 5 weeks & $\begin{array}{l}\text { CPTS-RI: } r= \\
0.56^{* *} \\
\text { Associated } \\
\text { with diagnosis } \\
\text { of PTSD } \\
\text { assessed by } \\
\text { CAPS-CA } r= \\
0.25^{*}\end{array}$ \\
\hline $\begin{array}{l}\text { Kunst et } \\
\text { al., } 2011\end{array}$ & 177 & $\begin{array}{l}\text { Survivors of } \\
\text { violence }\end{array}$ & Yes & $\begin{array}{l}\text { Mean } \\
(\mathrm{SD})= \\
4.2(3.2) \\
\text { years }\end{array}$ & $\begin{array}{l}\text { Mean } \\
(\mathrm{SD})= \\
4.2(3.2) \\
\text { years }\end{array}$ & $\begin{array}{l}\text { PSS-SR: } r= \\
0.43^{* * *}\end{array}$ \\
\hline $\begin{array}{l}\text { Maia et } \\
\text { al., } 2011\end{array}$ & 212 & $\begin{array}{l}\text { Active duty } \\
\text { police officers }\end{array}$ & Yes & $\begin{array}{l}\text { Not } \\
\text { reported }\end{array}$ & $\begin{array}{l}\text { Not } \\
\text { reported }\end{array}$ & $\begin{array}{l}\text { PCL-C: no } \\
\text { significant } \\
\text { relationship }\end{array}$ \\
\hline $\begin{array}{l}\text { Berna et } \\
\text { al., } 2012\end{array}$ & 155 & $\begin{array}{l}\text { Individuals } \\
\text { after MVC } \\
\text { admitted to } \\
\text { trauma service }\end{array}$ & Yes & $\leq 5$ days & 6 months & 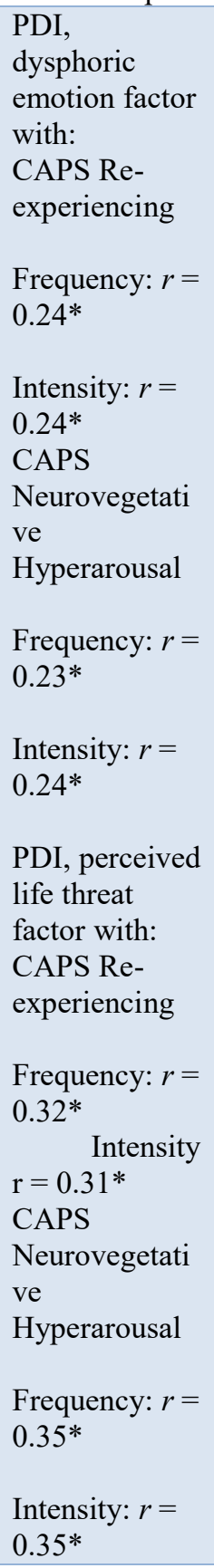 \\
\hline
\end{tabular}




\begin{tabular}{|c|c|c|c|c|c|c|c|}
\hline $\begin{array}{l}\text { Bui et al., } \\
2012\end{array}$ & 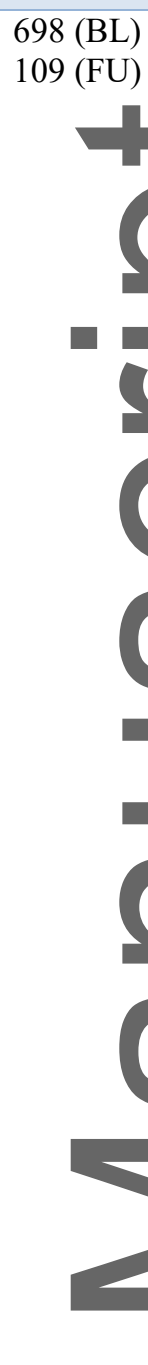 & $\begin{array}{l}\text { Adults after } \\
\text { media } \\
\text { exposure to } \\
\text { the March } \\
\text { 2011 Japan } \\
\text { earthquake }\end{array}$ & No & 2 weeks & $\begin{array}{l}\text { BL: } 2 \\
\text { weeks } \\
\text { FU: } 2 \\
\text { months }\end{array}$ & $\begin{array}{l}\text { In a } \\
\text { hierarchical } \\
\text { regression, } \\
\text { PDI predicted } \\
\text { IES-R scores } \\
\text { at } 2 \text { months }(\beta \\
\left.=0.58^{* *}\right) \text { after } \\
\text { controlling for } \\
\text { other } \\
\text { variables, } \\
\text { including age, } \\
\text { sex, and } \\
\text { peritraumatic } \\
\text { dissociation. }\end{array}$ & $\begin{array}{l}\text { In a } \\
\text { hierarchical } \\
\text { regression, PDI } \\
\text { predicted the } \\
\text { presence of at } \\
\text { least } 1 \text { instance } \\
\text { of disruptive } \\
\text { nocturnal sleep } \\
\text { (PSQI) } 1 \text { week } \\
\text { after } \\
\text { earthquake ( } \beta= \\
0.12^{* * *} \text { ) even } \\
\text { after } \\
\text { controlling for } \\
\text { other variables } \\
\text { including age, } \\
\text { sex, and } \\
\text { peritraumatic } \\
\text { dissociation. } \\
\text { Multiple } \\
\text { mediator } \\
\text { analysis } \\
\text { suggested that } \\
\text { peritraumatic } \\
\text { distress may } \\
\text { mediate the } \\
\text { relationship } \\
\text { between media } \\
\text { exposure to the } \\
\text { earthquake and } \\
\text { disruptive } \\
\text { nocturnal } \\
\text { behavior. }\end{array}$ \\
\hline $\begin{array}{l}\text { Hargrave } \\
\text { et al., } \\
2012\end{array}$ & 125 & $\begin{array}{l}\text { Adults after } \\
\text { loved one's } \\
\text { sudden death }\end{array}$ & Yes & $\begin{array}{l}24-39 \\
\text { months, } \\
\text { mean } \\
(\mathrm{SD})= \\
28.37 \\
(3.12) \\
\text { months }\end{array}$ & $\begin{array}{l}24-39 \\
\text { months, } \\
\text { mean } \\
(\mathrm{SD})= \\
28.37 \\
(3.12) \\
\text { months }\end{array}$ & $\begin{array}{l}\text { In a } \\
\text { hierarchical } \\
\text { regression, } \\
\text { PDI predicted } \\
\text { IES-R scores } \\
\left(\beta=0.42^{* *}\right) \\
\text { even after } \\
\text { controlling for } \\
\text { variables } \\
\text { including age } \\
\text { and gender. } \\
\\
\text { PDI continued } \\
\text { to be } \\
\text { significantly } \\
\text { associated } \\
\text { with IES-R } \\
\text { scores even } \\
\text { when taking } \\
\text { into account } \\
\text { ICG scores, } r \\
=0.35^{*} \text {. }\end{array}$ & $\begin{array}{l}\text { In a } \\
\text { hierarchical } \\
\text { regression, PDI } \\
\text { predicted } \\
\text { symptoms of } \\
\text { complicated } \\
\text { grief (ICG) ( } \beta= \\
\left.0.39^{* *}\right) \text { even } \\
\text { after } \\
\text { controlling for } \\
\text { variables } \\
\text { including age } \\
\text { and gender. } \\
\text { PDI continued } \\
\text { to be } \\
\text { significantly } \\
\text { associated with } \\
\text { ICG scores } \\
\text { even when } \\
\text { taking into } \\
\text { account IES-R } \\
\text { scores, } r=\end{array}$ \\
\hline
\end{tabular}




\begin{tabular}{|c|c|c|c|c|c|c|c|}
\hline & & & & & & & $0.20 *$ \\
\hline $\begin{array}{l}\text { Kunst et } \\
\text { al., } 2012\end{array}$ & 678 & $\begin{array}{l}\text { Individuals } \\
\text { after violent } \\
\text { crime }\end{array}$ & Yes & 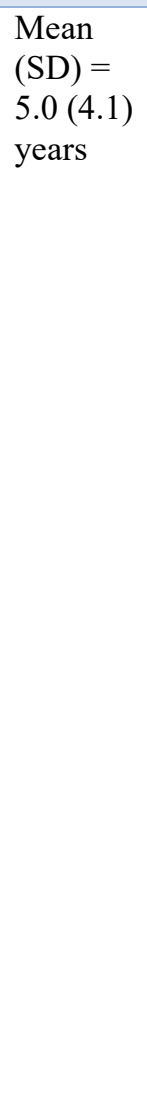 & $\begin{array}{l}\text { Mean } \\
(\mathrm{SD})= \\
5.0(4.1) \\
\text { years }\end{array}$ & $\begin{array}{l}\text { PSS-SR: } r= \\
\text { not reported, } \\
\text { but } \\
\text { significance } \\
\text { reported at } p= \\
0.002\end{array}$ & $\begin{array}{l}\text { In a } \\
\text { multivariate } \\
\text { regression } \\
\text { analysis, PDI } \\
\text { predicted } \\
\text { posttraumatic } \\
\text { growth (PTGI) } \\
\left(\beta=0.27^{* * *}\right) \\
\text { even after } \\
\text { controlling for } \\
\text { other variables, } \\
\text { including time } \\
\text { since } \\
\text { victimization, } \\
\text { age, sex, and } \\
\text { PTSD symptom } \\
\text { severity. } \\
\\
\text { Regression } \\
\text { indicated that } \\
\text { PDI may } \\
\text { moderate the } \\
\text { relationship } \\
\text { between } \\
\text { posttraumatic } \\
\text { symptoms and } \\
\text { posttraumatic } \\
\text { growth }\end{array}$ \\
\hline $\begin{array}{l}\text { Ladois- } \\
\text { Do et al., } \\
2012\end{array}$ & 70 & $\begin{array}{l}\text { Individuals } \\
\text { after } \\
\text { psychiatric } \\
\text { inpatient } \\
\text { admission }\end{array}$ & Mixed & $\begin{array}{l}<48 \\
\text { hours }\end{array}$ & 5 weeks & $\begin{array}{l}\text { PCL-S: } r= \\
0.44^{* *} \\
\text { In a multiple } \\
\text { regression, } \\
\text { PDI was the } \\
\text { only } \\
\text { significant } \\
\text { predictor of } \\
\text { PCL-S ( } \beta= \\
0.38^{* * *} \text { ) when } \\
\text { controlling for } \\
\text { other } \\
\text { variables, } \\
\text { including age, } \\
\text { sex, } \\
\text { peritraumatic } \\
\text { dissociation, } \\
\text { and previous } \\
\text { trauma } \\
\text { exposures. }\end{array}$ & \\
\hline $\begin{array}{l}\text { Letamen } \\
\text { dia et al., } \\
2012\end{array}$ & 25 & $\begin{array}{l}\text { Adults after } \\
\text { first stroke }\end{array}$ & Yes & $\begin{array}{l}<2 \\
\text { weeks }\end{array}$ & $\begin{array}{l}\text { FU1: } 5 \\
\text { weeks } \\
\text { FU2: } 3 \\
\text { months }\end{array}$ & $\begin{array}{l}\text { PCL, } \\
5 \text { weeks: } r \\
=0.59^{* *} \\
3 \text { months: } r \\
=0.36 \\
\text { In multiple }\end{array}$ & \\
\hline
\end{tabular}

This article is protected by copyright. All rights reserved. 


\begin{tabular}{|c|c|c|c|c|c|c|c|}
\hline & $\square$ & & & & & $\begin{array}{l}\text { regression } \\
\text { analyses, PDI } \\
\text { predicted 5- } \\
\text { week PCL } \\
\text { scores }(\beta= \\
0.59 * * *) \text { even } \\
\text { after } \\
\text { controlling for } \\
\text { gender. } \\
\text { However, in a } \\
\text { multiple } \\
\text { regression } \\
\text { controlling for } \\
\text { gender and 5- } \\
\text { week PCL } \\
\text { scores, PDI } \\
\text { did not predict } \\
\text { 3-month PCL } \\
\text { scores. }\end{array}$ & \\
\hline $\begin{array}{l}\text { Mutabar } \\
\text { uka et al., } \\
2012\end{array}$ & 102 & $\begin{array}{l}\text { Individuals } \\
\text { after the death } \\
\text { of family } \\
\text { member in } \\
\text { Rwandan } \\
\text { genocide }\end{array}$ & Yes & 12 years & 12 years & & $\begin{array}{l}\text { In a } \\
\text { hierarchical } \\
\text { regression, PDI } \\
\text { predicted } \\
\text { traumatic grief } \\
\text { (ITG) ( } \beta= \\
\left.0.38^{*}\right) \text { even } \\
\text { after } \\
\text { controlling for } \\
\text { variables } \\
\text { including age, } \\
\text { gender, } \\
\text { depressive } \\
\text { symptoms, and } \\
\text { PTSD } \\
\text { symptoms. } \\
\text { PDI also } \\
\text { mediated the } \\
\text { relationship } \\
\text { between } \\
\text { traumatic } \\
\text { exposure and } \\
\text { traumatic grief } \\
\text { symptoms } \\
\text { (Sobel test } \\
\text { statistic = } \\
2.92^{* *} \text { ). }\end{array}$ \\
\hline $\begin{array}{l}\text { Nishi et } \\
\text { al., } 2012\end{array}$ & $\begin{array}{l}254(\mathrm{BL}) \\
173(\mathrm{FU})\end{array}$ & $\begin{array}{l}\text { Rescue } \\
\text { workers after } \\
\text { March } 2011 \\
\text { Japan } \\
\text { Earthquake }\end{array}$ & Mixed & 1 month & 4 months & $\begin{array}{l}\text { IES-R: } \beta= \\
0.53^{* *} \text { in } \\
\text { univariate } \\
\text { analysis } \\
\text { In multiple } \\
\text { linear } \\
\text { regression, } \\
\text { PDI predicted } \\
\text { IES-R }(\beta= \\
\left.0.43^{* *}\right) \text { even } \\
\text { after }\end{array}$ & \\
\hline
\end{tabular}




\begin{tabular}{|c|c|c|c|c|c|c|c|}
\hline & & & & & & $\begin{array}{l}\text { controlling for } \\
\text { variables } \\
\text { including age, } \\
\text { sex, period of } \\
\text { deployment, } \\
\text { and stress } \\
\text { prior to } \\
\text { deployment. }\end{array}$ & \\
\hline $\begin{array}{l}\text { Pierce \& } \\
\text { Lilly, } \\
2012\end{array}$ & 171 & $\begin{array}{l}911 \\
\text { telecommunic } \\
\text { ators }\end{array}$ & Yes & $\begin{array}{l}\text { Not } \\
\text { assessed }\end{array}$ & $\begin{array}{l}\text { Not } \\
\text { assessed }\end{array}$ & $\begin{array}{l}\text { PDS: } r= \\
0.34 * * *\end{array}$ & \\
\hline $\begin{array}{l}\text { Rodgers } \\
\text { et al., } \\
2012\end{array}$ & 113 & $\begin{array}{l}\text { Adults after } \\
\text { media } \\
\text { exposure to } \\
\text { the March } \\
2011 \text { Japan } \\
\text { earthquake }\end{array}$ & No & $\begin{array}{l}\leq 2 \\
\text { weeks }\end{array}$ & 2 months & & $\begin{array}{l}\begin{array}{l}\text { Disordered } \\
\text { eating, EAT- } \\
26:\end{array} \quad \text { Total } \\
\text { Score: } r= \\
0.23^{*} \\
\quad \text { Dieting: } \\
r=0.18^{* * *} \\
\quad \text { Bulimia: } \\
r=0.27^{* *} \\
\text { In hierarchical } \\
\text { regression } \\
\text { analyses that } \\
\text { controlled for } \\
\text { media } \\
\text { exposure, } \\
\text { peritraumatic } \\
\text { dissociation, } \\
\text { and sleep, PDI } \\
\text { predicted } \\
\text { bulimia }(\beta= \\
\left.0.26^{* *}\right) \text {, but not } \\
\text { oral control, } \\
\text { dieting, or } \\
\text { disordered } \\
\text { eating. }\end{array}$ \\
\hline $\begin{array}{l}\text { Brunet et } \\
\text { al., } 2013\end{array}$ & 39 & $\begin{array}{l}\text { Elders older } \\
\text { than } 64 \text { after } \\
\text { physical } \\
\text { assault or road } \\
\text { traffic } \\
\text { accident }\end{array}$ & Yes & $\leq 1$ week & $\begin{array}{l}\text { FU1: } 1 \\
\text { month } \\
\text { FU2: } 6 \\
\text { months } \\
\text { FU3: } 12 \\
\text { months }\end{array}$ & $\begin{array}{l}\text { In a mixed } \\
\text { model } \\
\text { regression, } \\
\text { PCL: } t= \\
2.71^{* *}, d f= \\
116 \\
\text { CAPS score, } \\
t=2.47^{*}, d f= \\
77 \\
\text { CAPS } \\
\text { diagnosis, } t= \\
2.20^{*}, d f=77 \\
\text { Time, age, and }\end{array}$ & \\
\hline
\end{tabular}

This article is protected by copyright. All rights reserved. 


\begin{tabular}{|c|c|c|c|c|c|c|c|}
\hline & & & & & & $\begin{array}{l}\text { sex did not } \\
\text { have a } \\
\text { significant } \\
\text { effect. }\end{array}$ & \\
\hline $\begin{array}{l}\text { Favrole } \\
\text { et al., } \\
2013\end{array}$ & 40 & $\begin{array}{l}\text { Individuals } \\
\text { after a stroke }\end{array}$ & Yes & $\begin{array}{l}1-6 \\
\text { months }\end{array}$ & $\begin{array}{l}1-6 \\
\text { months }\end{array}$ & $\begin{array}{l}\text { Participants } \\
\text { with IES-R < } \\
30 \text { had } \\
\text { significantly } \\
\text { lower PDI } \\
\text { scores than } \\
\text { participants } \\
\text { with IES-R > } \\
30, p=0.001 .\end{array}$ & \\
\hline $\begin{array}{l}\text { Guardia } \\
\text { et al., } \\
2013\end{array}$ & 192 & $\begin{array}{l}\text { Individuals } \\
\text { after MVC }\end{array}$ & Yes & $\leq 5$ days & 6 weeks & $\begin{array}{l}\text { PDI was } \\
\text { associated } \\
\text { with a greater } \\
\text { risk of acute } \\
\text { PTSD } \\
\text { (CAPS), } \chi 2= \\
5.15, d f=1, p \\
=0.02 .\end{array}$ & \\
\hline $\begin{array}{l}\text { Kunst et } \\
\text { al., } 2013\end{array}$ & 95 & $\begin{array}{l}\text { Individuals } \\
\text { after domestic } \\
\text { burglary }\end{array}$ & Mixed & $\begin{array}{l}\text { Mean } \\
(\mathrm{SD})= \\
19.1 \\
(5.2) \\
\text { days }\end{array}$ & $\begin{array}{l}4-6 \\
\text { weeks } \\
\text { after the } \\
\text { first } \\
\text { intervie } \\
\text { w }\end{array}$ & $\begin{array}{l}\text { TSQ: } r= \\
0.63^{* * *} \\
\text { PSS-SR: } r= \\
0.51 * * *\end{array}$ & \\
\hline $\begin{array}{l}\text { Cénat \& } \\
\text { Derivois, } \\
2014\end{array}$ & 1355 & $\begin{array}{l}\text { Adults after } \\
2010 \text { Haiti } \\
\text { earthquake }\end{array}$ & Yes & $\begin{array}{l}30 \\
\text { months }\end{array}$ & $\begin{array}{l}30 \\
\text { months }\end{array}$ & $\begin{array}{l}\text { IES-R: } r= \\
0.61^{* *} \\
\text { In a } \\
\text { multivariate } \\
\text { regression, } \\
\text { PDI predicted } \\
\text { IES-R }(\beta= \\
\left.0.57^{* * *}\right) \text { after } \\
\text { controlling for } \\
\text { variables } \\
\text { including age, } \\
\text { gender, } \\
\text { education, } \\
\text { employment } \\
\text { status, life } \\
\text { events before } \\
\text { and after the } \\
\text { earthquake, } \\
\text { and traumatic } \\
\text { exposure } \\
\text { level. }\end{array}$ & $\begin{array}{l}\text { Depressive } \\
\text { symptoms, } \\
\text { BDI: } \\
r=0.31^{* *} \\
\text { In a } \\
\text { multivariate } \\
\text { regression, PDI } \\
\text { predicted } \\
\text { depressive } \\
\text { symptoms } \\
(\text { BDI) }(\beta= \\
\left.0.21^{* * *}\right) \text { after } \\
\text { controlling for } \\
\text { variables } \\
\text { including age, } \\
\text { gender, } \\
\text { education, } \\
\text { employment } \\
\text { status, life } \\
\text { events before } \\
\text { and after the } \\
\text { earthquake, and } \\
\text { traumatic } \\
\text { exposure level. }\end{array}$ \\
\hline $\begin{array}{l}\text { Lewis et } \\
\text { al., } 2014\end{array}$ & 935 & $\begin{array}{l}\text { Individuals } \\
\text { after a MVC }\end{array}$ & Yes & $<1$ week & $<1$ week & & $\begin{array}{l}\text { Female gender, } \\
\text { trait anxiety, } \\
\text { vehicle } \\
\text { damage, and } \\
\text { depressive }\end{array}$ \\
\hline
\end{tabular}




\begin{tabular}{|c|c|c|c|c|c|c|c|}
\hline & - & & & & & & $\begin{array}{l}\text { symptoms in } \\
\text { the month prior } \\
\text { to crash } \\
\text { predicted PDI } \geq \\
23(p<0.001) \text {. } \\
\text { PDI predicted } \\
\text { less confidence } \\
\text { in full recovery } \\
(p<0.01) \text { and } \\
\text { less expected } \\
\text { time to } \\
\text { emotional } \\
\text { recovery }<30 \\
\text { days }(p< \\
0.001) .\end{array}$ \\
\hline $\begin{array}{l}\text { Shigemur } \\
\text { a et al., } \\
2014\end{array}$ & $\begin{array}{l}831 \text { at } \\
\text { Daiichi; } \\
580 \text { at } \\
\text { Daini }\end{array}$ & $\begin{array}{l}\text { Individuals } \\
\text { after the } \\
\text { Daiichi and } \\
\text { Daini nuclear } \\
\text { power plant } \\
\text { accidents }\end{array}$ & Mixed & $\begin{array}{l}2-3 \\
\text { months }\end{array}$ & $\begin{array}{l}2-3 \\
\text { months }\end{array}$ & $\begin{array}{l}\text { In participants } \\
\text { at Daiichi, } \\
\text { PDI predicted } \\
\text { IES-R in a } \\
\text { bivariate } \\
\text { regression }(\beta= \\
\left.0.66^{* * *}\right) \text { and } \\
\text { in a multiple } \\
\text { regression }(\beta= \\
\left.0.66^{* * *}\right) \text { that } \\
\text { controlled for } \\
\text { sociodemogra } \\
\text { phic factors } \\
\text { and disaster- } \\
\text { related } \\
\text { experiences. } \\
\\
\text { In participants } \\
\text { at Daini, PDI } \\
\text { predicted IES- } \\
\text { R in a } \\
\text { bivariate } \\
\text { regression }(\beta= \\
0.67 * *) \text { and } \\
\text { in a multiple } \\
\text { regression }(\beta= \\
\left.0.63^{* * *}\right) \text { that } \\
\text { controlled for } \\
\text { sociodemogra } \\
\text { phic factors } \\
\text { and disaster- } \\
\text { related } \\
\text { experiences. }\end{array}$ & \\
\hline $\begin{array}{l}\text { Pereira et } \\
\text { al., } 2014\end{array}$ & 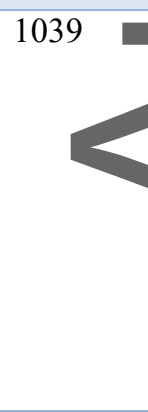 & $\begin{array}{l}\text { Older ( } \geq 65 \\
\text { years) and } \\
\text { younger (18- } \\
64 \text { years) } \\
\text { adults after } \\
\text { MVC }\end{array}$ & Yes & $<1$ week & $<1$ week & & $\begin{array}{l}\text { Depressive } \\
\text { symptoms and } \\
\text { pain } \\
\text { catastrophizing } \\
\text { pre-MVC were } \\
\text { positively } \\
\text { associated with } \\
\text { pain and PDI in } \\
\text { both older and } \\
\text { younger adults. }\end{array}$ \\
\hline
\end{tabular}




\begin{tabular}{|c|c|c|c|c|c|c|c|}
\hline $\begin{array}{l}\text { Blanc et } \\
\text { al., } 2015\end{array}$ & 110 & $\begin{array}{l}\text { Children after } \\
\text { earthquake }\end{array}$ & Yes & $\begin{array}{l}>1 \\
\text { month }\end{array}$ & $\begin{array}{l}>1 \\
\text { month }\end{array}$ & $\begin{array}{l}\text { CPTS-RI, } \\
\text { Total: } r= \\
0.44^{* *} \\
\quad \text { Re- } \\
\text { experiencing: } \\
r=0.43^{* *} \\
\text { Avoidance: } r \\
=0.25^{*}\end{array}$ & \\
\hline $\begin{array}{l}\text { Lavoie et } \\
\text { al., } 2015\end{array}$ & 35 & $\begin{array}{l}\text { Emergency } \\
\text { room nurses }\end{array}$ & Mixed & $<1$ year & $<1$ year & $\begin{array}{l}\text { IES-R: Total: } \\
r=0.58^{* *} \\
\quad \text { Re- } \\
\text { experiencing: } \\
r=0.46^{* *} \\
\text { Avoidance: } r \\
=0.49^{* *} \\
\text { Hyperactivity: } \\
r=0.65^{* *}\end{array}$ & \\
\hline $\begin{array}{l}\text { Cénat \& } \\
\text { Derivois, } \\
2015\end{array}$ & 872 & $\begin{array}{l}\text { Children after } \\
2010 \text { Haiti } \\
\text { earthquake }\end{array}$ & Yes & $\begin{array}{l}30 \\
\text { months }\end{array}$ & $\begin{array}{l}30 \\
\text { months }\end{array}$ & $\begin{array}{l}\text { IES-R: } r= \\
0.57^{* *} \\
\text { In a } \\
\text { multivariate } \\
\text { regression, } \\
\text { PDI predicted } \\
\text { IES-R }(\beta= \\
\left.0.53^{* * *}\right) \text { after } \\
\text { controlling for } \\
\text { age, sex, } \\
\text { traumatic } \\
\text { experience } \\
\text { before and } \\
\text { after the } \\
\text { earthquake, } \\
\text { and traumatic } \\
\text { exposure to } \\
\text { the } \\
\text { earthquake. }\end{array}$ & $\begin{array}{l}\text { In a } \\
\text { multivariate } \\
\text { regression, PDI } \\
\text { predicted } \\
\text { depressive } \\
\text { symptoms } \\
(\mathrm{BDI})(\beta= \\
\left.0.13^{* * *}\right) \text { after } \\
\text { controlling for } \\
\text { age, sex, } \\
\text { traumatic } \\
\text { experience } \\
\text { before and after } \\
\text { the earthquake, } \\
\text { and traumatic } \\
\text { exposure to the } \\
\text { earthquake. }\end{array}$ \\
\hline $\begin{array}{l}\text { Brock et } \\
\text { al., } 2015\end{array}$ & 171 & $\begin{array}{l}\text { Perinatal } \\
\text { women } \\
\text { exposed to the } \\
2008 \text { Iowa } \\
\text { floods }\end{array}$ & Yes & $\begin{array}{l}\text { Mean } \\
(\mathrm{SD})= \\
3.47 \\
(4.90) \\
\text { months } \\
\text { after } \\
\text { peak of } \\
\text { the } \\
\text { floods, } \\
\text { range = } \\
0.95- \\
24.67 \\
\text { months } \\
\text { post- } \\
\text { flood }\end{array}$ & $\begin{array}{l}5 \text { time } \\
\text { points } \\
\text { from } \\
\text { pregnanc } \\
\text { y to } 30 \\
\text { months } \\
\text { postpart } \\
\text { um }\end{array}$ & & $\begin{array}{l}\text { PDI correlated } \\
\text { with IDAS } \\
\text { depression at } 4 \\
\text { months } \\
\text { antepartum, } 2 \\
\text { months } \\
\text { antepartum, } 16 \\
\text { months } \\
\text { postpartum, and } \\
18 \text { months } \\
\text { postpartum ( } p< \\
0.01) ; \text { PDI } \\
\text { correlated with } \\
\text { IDAS well- } \\
\text { being at } 4 \\
\text { months } \\
\text { antepartum ( } p< \\
0.01) \text { and } 2 \\
\text { months }\end{array}$ \\
\hline
\end{tabular}

This article is protected by copyright. All rights reserved. 


\begin{tabular}{|c|c|c|c|c|c|c|c|}
\hline & & & & & & & $\begin{array}{l}\text { antepartum }(p< \\
0.05) . \\
\text { Peritraumatic } \\
\text { distress } \\
\text { mediated the } \\
\text { effect of flood } \\
\text { exposure on } \\
\text { depression. }\end{array}$ \\
\hline $\begin{array}{l}\text { Blanc et } \\
\text { al., } 2016\end{array}$ & 167 & $\begin{array}{l}\text { Adults after } \\
2010 \text { Haiti } \\
\text { earthquake }\end{array}$ & Yes & $\begin{array}{l}\sim 27 \\
\text { months } \\
\text { (earthqu } \\
\text { ake in } \\
\text { January } \\
2010 \text {, } \\
\text { study in } \\
\text { April } \\
2012 \text { ) }\end{array}$ & $\begin{array}{l}27 \\
\text { months } \\
\text { (earthqu } \\
\text { ake in } \\
\text { January } \\
2010, \\
\text { study in } \\
\text { April } \\
2012 \text { ) }\end{array}$ & $\begin{array}{l}\text { PCL-S: } r= \\
0.523^{* *} \\
\text { In multiple } \\
\text { linear } \\
\text { regressions, } \\
\text { peritraumatic } \\
\text { distress was } \\
\text { the best } \\
\text { predictor for } \\
\text { PTSD } \\
\text { symptoms ( } \beta= \\
0.366, p< \\
0.001) \text {, above } \\
\text { religious } \\
\text { affiliation }(\beta= \\
0.155, p< \\
0.001) \text { and } \\
\text { peritraumatic } \\
\text { dissociation }(\beta \\
=0.221, p< \\
0.001) \text {. }\end{array}$ & $\begin{array}{l}\text { Depressive } \\
\text { symptoms, } \\
\text { BDI: } \\
r=0.326^{* *}\end{array}$ \\
\hline $\begin{array}{l}\text { Hetzel- } \\
\text { Riggin } \\
\text { and } \\
\text { Meads, } \\
2016\end{array}$ & 227 & $\begin{array}{l}\text { Eollege } \\
\text { students after } \\
\text { mixed trauma }\end{array}$ & Yes & $\begin{array}{l}\text { Variable } \\
\text { (assesse } \\
\mathrm{d} \text { for } \\
\text { lifetime } \\
\text { trauma) }\end{array}$ & $\begin{array}{l}\text { Variable } \\
\text { (assesse } \\
\text { d for } \\
\text { lifetime } \\
\text { trauma) }\end{array}$ & $\begin{array}{l}\text { Latent } \\
\text { measure of } \\
\text { PTSD: } r= \\
0.33^{* * *}\end{array}$ & \\
\hline $\begin{array}{l}\text { Hiar et } \\
\text { al., } 2016\end{array}$ & 60 & $\begin{array}{l}\text { Individuals } \\
\text { after Arab } \\
\text { Spring riots in } \\
\text { Tunisia }\end{array}$ & Mixed & 1 year & 1 year & $\begin{array}{l}\text { PCL: } r= \\
0.50^{* * *} \\
\text { Peritraumatic } \\
\text { distress was } \\
\text { not found to } \\
\text { be } \\
\text { independently } \\
\text { associated } \\
\text { with PTSD } \\
\text { symptoms and } \\
\text { somatic } \\
\text { symptoms in } \\
\text { regression } \\
\text { analyses. }\end{array}$ & $\begin{array}{l}\text { Somatic } \\
\text { symptoms, } \\
\text { PHQ: } \\
r=0.43^{* * *} \\
\text { Functional } \\
\text { health, PCS: } \\
r=-0.39^{* * *} \\
\text { Mental well- } \\
\text { being, MCS: } \\
r=-0.40^{* * *}\end{array}$ \\
\hline $\begin{array}{l}\text { Lilly, } \\
\text { London, } \\
\text { and } \\
\text { Mercer } \\
2016\end{array}$ & 758 & $\begin{array}{l}911 \\
\text { telecommunic } \\
\text { ators }\end{array}$ & Yes & $\begin{array}{l}\text { Not } \\
\text { reported }\end{array}$ & $\begin{array}{l}\text { Not } \\
\text { reported }\end{array}$ & $\begin{array}{l}\text { PCL: } r= \\
0.51^{*}\end{array}$ & $\begin{array}{l}\text { Physical health, } \\
\text { PILL: } \\
r=0.38^{*} \\
\text { Depressive } \\
\text { symptoms, } \\
\text { BDI: } \\
r=0.40^{*}\end{array}$ \\
\hline
\end{tabular}

This article is protected by copyright. All rights reserved. 


\begin{tabular}{|c|c|c|c|c|c|c|c|}
\hline $\begin{array}{l}\text { Kawashi } \\
\text { ma et al., } \\
2016\end{array}$ & $\begin{array}{l}254(\mathrm{BL}) \\
188(\mathrm{FU})\end{array}$ & $\begin{array}{l}\text { Medical } \\
\text { rescue } \\
\text { workers after } \\
\text { the Great East } \\
\text { Japan } \\
\text { Earthquake }\end{array}$ & Yes & 1 month & 4 years & $\begin{array}{l}\text { In univariate } \\
\text { analyses, BL } \\
\text { PDI predicted } \\
\text { FU IES-R ( } \beta= \\
\left.0.38^{* *}\right) \text {. } \\
\text { In multivariate } \\
\text { analyses, BL } \\
\text { PDI predicted } \\
\text { FU IES-R ( } \beta= \\
\left.0.35^{* *}\right) \text { when } \\
\text { controlling for } \\
\text { variables } \\
\text { including age, } \\
\text { sex, period of } \\
\text { deployment, } \\
\text { stress prior to } \\
\text { deployment, } \\
\text { experience of } \\
\text { contact with } \\
\text { corpses, and } \\
\text { concern over } \\
\text { radiation } \\
\text { exposure. }\end{array}$ & $\begin{array}{l}\text { In univariate } \\
\text { analyses, BL } \\
\text { PDI predicted } \\
\text { burnout at FU } \\
\text { measured by } \\
\text { MBI }(\beta= \\
\left.0.27^{* *}\right) \text {. } \\
\text { In multivariate } \\
\text { analyses, BL } \\
\text { PDI predicted } \\
\text { FU MBI ( } \beta= \\
\left.0.21^{* *}\right) \text { when } \\
\text { controlling for } \\
\text { variables } \\
\text { including age, } \\
\text { sex, period of } \\
\text { deployment, } \\
\text { stress prior to } \\
\text { deployment, } \\
\text { experience of } \\
\text { contact with } \\
\text { corpses, and } \\
\text { concern over } \\
\text { radiation } \\
\text { exposure. }\end{array}$ \\
\hline $\begin{array}{l}\text { Nishi et } \\
\text { al., } 2016\end{array}$ & $\begin{array}{l}191(\mathrm{FU} \\
\text { from Nis } \\
2012 \\
\text { sample) }\end{array}$ & $\begin{array}{l}\text { Rescue } \\
\text { workers } 4 \\
\text { years after } \\
\text { March } 2011 \\
\text { Japan } \\
\text { Earthquake }\end{array}$ & Mixed & 1 month & 4 years & & $\begin{array}{l}\text { Resilience, RS- } \\
14: \\
r=-0.20^{* *} \\
\text { Post-traumatic } \\
\text { growth, PTGI } \\
\text { total score: } r= \\
0.31^{* *}\end{array}$ \\
\hline $\begin{array}{l}\text { Kunst } \\
\text { and } \\
\text { Koster, } \\
2016\end{array}$ & 201 & $\begin{array}{l}\text { Survivors of } \\
\text { domestic } \\
\text { burglary or } \\
\text { violent crime }\end{array}$ & Mixed & $\begin{array}{l}<1 \\
\text { month }\end{array}$ & 2 months & $\begin{array}{l}\text { TSQ: } r= \\
0.61^{* * *} \\
\text { In regression } \\
\text { analyses, PDI } \\
\text { predicted TSQ } \\
1 \text { month later, } \\
\beta=0.43^{* * *}, \\
\text { controlling for } \\
\text { sex, age, crime } \\
\text { type, } \\
\text { recognition } \\
\text { deficits, fear } \\
\text { of } \\
\text { personal/prope } \\
\text { rty crime } \\
\text { victimization, } \\
\text { and anger } \\
\text { towards } \\
\text { perpetrator. }\end{array}$ & \\
\hline $\begin{array}{l}\text { Tanisho } \\
\text { et al., } \\
2016\end{array}$ & $\begin{array}{l}571 \text { at } \\
\text { Daiichi; } \\
397 \text { at } \\
\text { Daini }\end{array}$ & $\begin{array}{l}\text { Individuals } \\
\text { after the } \\
\text { Daiichi and } \\
\text { Daini nuclear } \\
\text { power plant } \\
\text { accidents }\end{array}$ & Mixed & $\begin{array}{l}2-3 \\
\text { months }\end{array}$ & $\begin{array}{l}\mathrm{BL}=2-3 \\
\text { months } \\
\mathrm{FU}=14- \\
15 \\
\text { months }\end{array}$ & $\begin{array}{l}\text { IES-R at BL: } r \\
=0.68^{* * *} \\
\text { PDI did not } \\
\text { predict FU } \\
\text { IES-R in }\end{array}$ & $\begin{array}{l}\text { Psychological } \\
\text { Distress, K6 at } \\
\text { BL: } \\
r=0.68 * * * \\
\text { PDI did not }\end{array}$ \\
\hline
\end{tabular}




\begin{tabular}{|c|c|c|c|c|c|c|c|}
\hline & & & & & & $\begin{array}{l}\text { hierarchical } \\
\text { models. }\end{array}$ & $\begin{array}{l}\text { predict FU K6 } \\
\text { in hierarchical } \\
\text { models. }\end{array}$ \\
\hline $\begin{array}{l}\text { Gandube } \\
\text { rt et al., } \\
2016\end{array}$ & $\begin{array}{l}123 \text { (BL) } \\
89 \text { (FU1) } \\
85 \text { (FU2) } \\
57 \text { (FU3) }\end{array}$ & $\begin{array}{l}\text { Civilians } \\
\text { presenting to } \\
\text { emergency } \\
\text { department } \\
\text { with recent } \\
D S M-I V \\
\text { Criterion A1 } \\
\text { trauma }\end{array}$ & Yes & 2-7 days & $\begin{array}{l}\text { FU1 }=1 \\
\text { month } \\
\text { FU2 = 4 } \\
\text { months } \\
\text { FU3 = } \\
12 \\
\text { months }\end{array}$ & $\begin{array}{l}\text { In logistic } \\
\text { regression, BL } \\
\text { PDI predicted } \\
\text { onset of PTSD } \\
\text { at } \\
\text { FU1: OR } \\
{[95 \% \text { CI] }=} \\
1.11[1.04- \\
1.18]^{* *} \\
\text { FU2: OR } \\
{[95 \% \text { CI] }=} \\
1.09[1.02- \\
1.16]^{*} \\
\text { In multiple } \\
\text { logistic } \\
\text { regression } \\
\text { controlling for } \\
\text { age, sex, } \\
\text { biological } \\
\text { variables (e.g., } \\
\text { cortisol and } \\
\text { norepinephrin } \\
\text { e), and PDEQ, } \\
\text { BL PDI } \\
\text { predicted } \\
\text { onset of PTSD } \\
\text { (assessed by } \\
\text { PTSD-I) at } \\
\text { FU1: OR } \\
{[95 \% \text { CI }]=} \\
1.09[1.00- \\
1.18]^{*} \text {. }\end{array}$ & \\
\hline $\begin{array}{l}\text { Derivois } \\
\text { et al., } \\
2017\end{array}$ & 128 & $\begin{array}{l}\text { reet children } \\
\text { no survived } \\
\text { 2010 Haiti } \\
\text { rthquake }\end{array}$ & Yes & 4 years & 4 years & $\begin{array}{l}\text { CRIES: } r= \\
0.43^{* *} \\
\text { In multivariate } \\
\text { regression, } \\
\text { PDI predicted } \\
\text { PTSD } \\
\text { symptoms } \\
\text { (CRIES), } \beta= \\
0.39 * * * \\
\text { controlling for } \\
\text { other } \\
\text { traumatic life } \\
\text { events and } \\
\text { violent } \\
\text { experiences } \\
\text { and age. }\end{array}$ & $\begin{array}{l}\text { Depressive } \\
\text { symptoms, } \\
\text { CDI: } \\
r=0.2^{*} \\
\text { Anxiety } \\
\text { symptoms, } \\
\text { BAI: } \\
r=0.52^{* *} \\
\text { In multivariate } \\
\text { regression, PDI } \\
\text { predicted } \\
\text { depressive } \\
\text { symptoms } \\
\text { (CDI), } \beta= \\
0.13^{* *} \text {, and } \\
\text { anxiety } \\
\text { symptoms } \\
\text { (BAI), } \beta= \\
0.48^{* * *}, \\
\text { controlling for }\end{array}$ \\
\hline
\end{tabular}




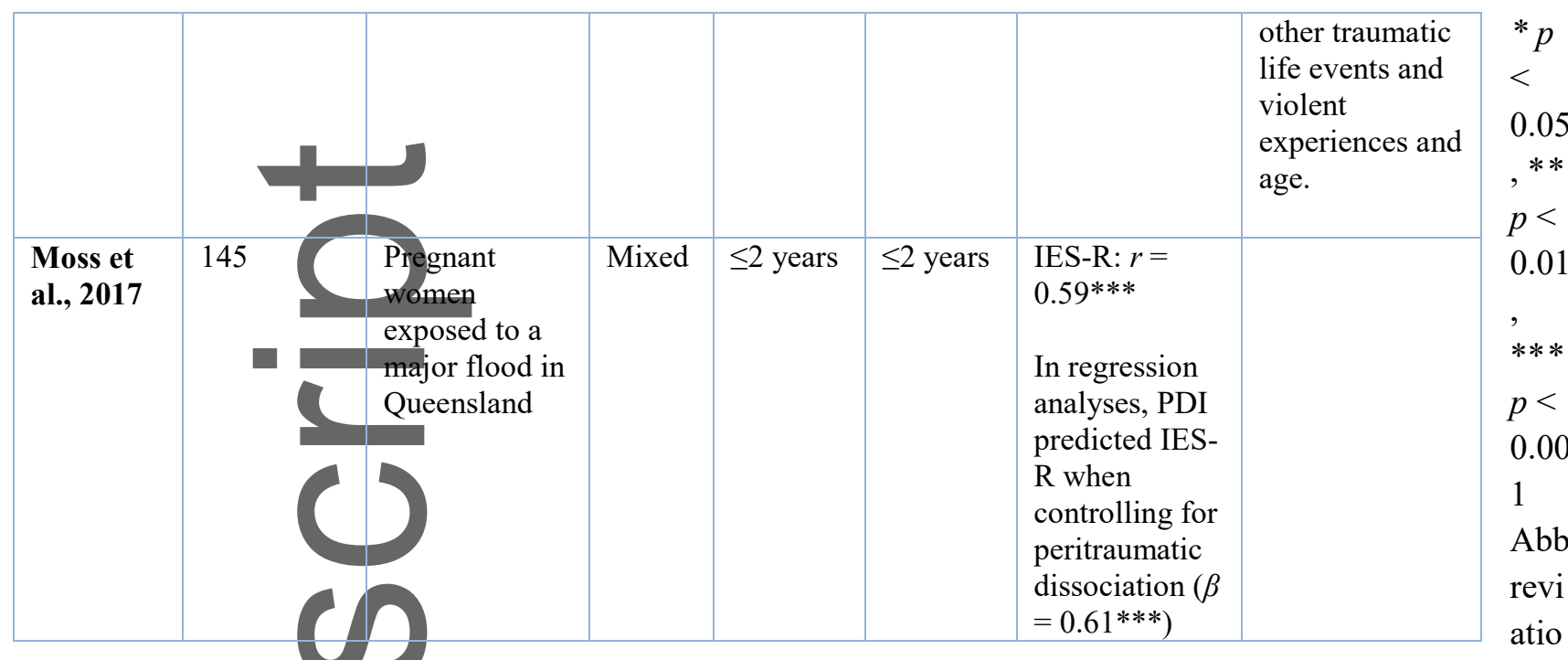

ns: $\mathrm{BL}=$ baseline; $F U$ = follow-up; FU1 = first follow-up; FU2 = second follow-up; FU3 = third follow-up; $\mathrm{MVC}=$ motor vehicle collision; $\mathrm{ASD}=$ acute stress disorder; BDI = Beck Depression Inventory; CAPS = Clinician-Administered PTSD Scale; CAPS-CA = Clinician-Administered PTSD Scale Child and Adolescent; CMS = Civilian Mississippi Scale (civilian version of Mississippi Scale for Combat-Related PTSD); CPTS-RI = Child Posttraumatic Stress Reaction Index; CRIES = Children's Revised Impact of Event Scale; DES = Dissociative Experiences Scale; EAT-26 = 26-Item Eating Attitudes Test; HADS $=$ Hospital Anxiety and Depression Scale; IDAS = Inventory of Depression and Anxiety Symptoms; IES-R = Impact of Event Scale Revised; ITG = Inventory of Traumatic Grief; K 6 = Kessler Psychological Distress Scale; MBI = Maslach Burnout Inventory; MCS = Mental Composite Score; PCL = PTSD Checklist; PCL-C = PTSD Checklist Civilian; PCL-S $=$ PTSD Checklist Specific; PCS $=$ Physical Composite Score PDEQ $=$ Peritraumatic Dissociative Experiences Questionnaire; PDI $=$ Peritraumatic Distress Inventory; PDS $=$ Posttraumatic Stress Diagnostic Scale; PHQ = Patient Health Questionnaire; PILL = Pennebaker Inventory of Limbic Languidness; PSS-SR = PTSD Symptom Scale Self-Report; PTGI = Posttraumatic Growth Inventory; PTSD = posttraumatic stress disorder; PTSD-I = PTSD Interview; Resilience Scale (RS-14); TSQ = Trauma Screener Questionnaire

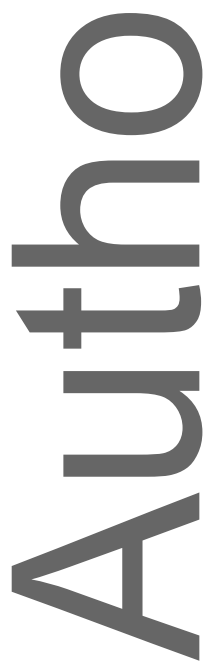

